\title{
Mikveh and the Sanctity of Being Created Human
}

\author{
Susan Grossman
}

This paper was approved by the CJLs on September 13, 2006 by a vote of fourteen in favor, one opposed and four abstaining (14-1-4). Members voting in favor: Rabbis Kassel Abelson, Elliot Dorff, Aaron Mackler, Robert Harris, Robert Fine, David Wise, Daniel Nevins, Alan Lucas, Joel Roth, Myron Geller, Pamela Barmash, Gordon Tucker, Vernon Kurtz, and Susan Grossman. Members voting against: Rabbi Leonard Levy. Members abstaining: Rabbis Joseph Prouser, Loel Weiss, Paul Plotkin, and Avram Reisner.

\section{Sheilah}

How should we, as modern Conservative Jews, observe the laws traditionally referred to under the rubric Tohorat HaMishpahah (The Laws of Family Purity) ? $^{1}$

\section{Teshuvah}

\section{Introduction}

Judaism is our path to holy living, for turning the world as it is into the world as it can be. The Torah is our guide for such an ambitious aspiration, sanctified by the efforts of hundreds of generations of rabbis and their communities to

1 The author wishes to express appreciation to all the following who at different stages commented on this work: Dr. David Kraemer, Dr. Shaye Cohen, Dr. Seth Schwartz, Dr. Tikva Frymer-Kensky, z"l, Rabbi James Michaels, Annette Muffs Botnick, Karen Barth, and the members of the CJLS Sub-Committee on Human Sexuality. I particularly want to express my appreciation to Dr. Joel Roth. Though he never published his halakhic decisions on tohorat mishpahah ("family purity"), his lectures and teaching guided countless rabbinical students and rabbinic colleagues on this subject. In personal communication with me, he confirmed that the below psak (legal decision) and reasoning offered in his name accurately reflects his teaching. The positions otherwise expressed in this paper, as well as any errors, remain my own. (Minor editorial changes have been made in the version printed here which have no effect on the substance or conclusions of this teshuvah presented and approved in 2006.) 
interpret and apply its teachings to the large and small questions of living in the real world. This is true for the grand ethical statements of the Torah, such as, "Justice, justice shall you pursue,"2 as well as for the detailed directives that guide our most personal activities. ${ }^{3}$

The laws relating to a woman's menstrual period and the appropriateness of sexual activity during it certainly fall within these most intimate of categories.

At first glance, the original Levitical context for the source of these laws (the diagnosis and public safety protocols for skin diseases and genital discharges) might be more appropriate for inclusion in an ancient medical text. In this context, the priest of the Biblical period served as diagnostician and doctor, as well as pastor (in the sense of visiting the sick), in addition to his other cultic responsibilities dealing with the sacrifices and the care of the central sanctuary. (Women never served as priests, per se, although women of priestly families enjoyed some priestly privileges, such as eating of the priestly portion of the sacrifices.)

Nevertheless, generations of Jews interpreted the words of Leviticus 15:1924 in conjunction with those of Leviticus 18:19 as prohibiting sexual relations. These laws were grouped together under the rubrics of Hilkhot Niddah or more recently Tohorat HaMishpahah, the Laws of Family Purity, still observed today in many observant communities. Traditional practice prohibits all physical contact between a woman and her husband during her menses and for seven "clean" or "white" days following the cessation of any appearance of blood. ${ }^{4}$ Intimate relations, or any physical contact, are not to be resumed until the woman immerses in a mikveh, a ritual pool. From the onset of menstrual symptoms until immersion in the mikveh, the woman is considered a niddah and ritually impure.

Much has been written about the cultural and psychological significance of the menstrual laws. ${ }^{5}$ They contain the potential for great beauty and significance but have also been the source of great pain and prejudice.

2 Deut 16:20.

3 My colleague R. Joshua Gutoff many years ago suggested that the modern aversion to giving up our autonomy over what might be perceived of as purely personal activities may be largely responsible for the fact that halakhic restrictions on sexuality have largely fallen into disuse, even among those who are otherwise observant outside the Orthodox community.

4 Traditionally this was interpreted to mean a minimum of twelve days of separation, a minimum of five for the woman's period plus seven "white" days.

5 E.g., Jacob Milgrom, "Comments-Genital Discharges," in his Leviticus 1-16, Anchor Bible 3 (New York: Doubleday, 1991), 948-10o9; David Kraemer, "A Developmental Perspective on the Laws of Niddah," Conservative Judaism 38, no. 3 (Spring 1986): 26-33.

For Conservative halakhah, see: Isaac Klein, A Guide to Jewish Religious Practice (New York: Jewish Theological Seminary, 1979), 510-522, who permits an outdoor, in ground swimming 
The development and observance of these laws in Judaism have been criticized as reflecting the primal fear of blood, as reflected in cultural blood taboos, ${ }^{6}$ and the casting of women as "other" in a society defined by men. Such critiques found cause in how the menstrual laws were expanded over the centuries to proscribe a menstruant's contact with the Torah and involvement in the synagogue and even in familial society. However, as we will see below, such rules, which compromised the existential beauty of mikveh and the sanctification of a woman's bodily cycle, particularly in the context of marriage, were not based on Jewish law and therefore could be easily and appropriately relegated to folkways.

In their place, a growing number of Jewish women turned to the observance of the laws of Hilkhot Niddah as an area of "women's mitzvot," " women's commandments. This is part of a larger effort on the part of Jewish women during

pool to be used when a mikveh or other source of living water is not available, following a Law Committee decision based on the teshuvah (responsa), "May a Swimming Pool be Used as a Mikveh?" by R. Kreitman (p. 522). The articles, "Niddah," and "Purity and Impurity," Encyclopedia Judaica 12:1141-1148; 13:1410 ff., offer a brief survey of relevant sources.

For modern Jewish responses, see: Rachel Adler, "Tumah and Taharah-Mikveh," in The First Jewish Catalogue (Philadelphia:Jewish Publication Society, 1973), 167-171, also published in The Jewish Woman: An Anthology, ed. Liz Koltun (Philadelphia: Jewish Publication Society, 1973), 117-127. Adler rebuts her original position in "In Your Blood, Live: Re-Visions of a Theology of Purity," Tikkun 8, no.1 (1993):38-41. See also, Susan Grossman, "Feminism, Midrash, and Mikveh," Conservative Judaism 44, no. 2 (Winter 1992): 7-17, and People of the Body:Jews and Judaism from an Embodied Perspective, ed. Howard Eilberg-Schwartz (Albany: SUNY, 1992).

Many books have been written from the Orthodox perspective. The most popular include Norman Lamm, A Hedge of Roses: Jewish Insights into Marriage and Married Life (New York: Feldheim, 1966); and the mystical approach of Aryeh Kaplan, Waters of Eden: An Exploration of the Concept of Mikvah (New York: National Conference of Synagogue Youth, 1976), esp. 4O46, 62-73. Blu Greenberg offers an Orthodox-Feminist defense, "In Defense of the 'Daughters of Israel': Observations on Niddah and Mikveh," in her On Women and Judaism: A View from Tradition (Philadelphia: Jewish Publication Society, 1981).

For comparative material, see James Frazer, The Golden Bough (New York: Avenel, 1981), ch. 2, "The Perils of the Soul," 1:109-212; and Robert Parker, Miasma:Pollution and Purification in Early Greek Religion (Oxford: Oxford University Press, 1983).

6 On blood taboos, see Mary Douglas, Purity and Danger: An Analysis of Concepts of Pollution and Taboo (London: Routledge and Kegan Paul, 1966; London: Ark Paperbacks, 1984); Milgrom, "Comments," 949; Kraemer, "A Developmental Perspective," 33. See also n. 8 below. A comparison between rabbinic and contemporaneous, e.g. Hellenistic, attitudes toward the menstruant and parturient is beyond the scope of this particular teshuvah.

7 Cf. m. Šabb. 2:6; AdRNB ch. 9 (Schechter, p. 25) and ch. 42 end (Schechter, p. 117), b. Šabb. 31b32a, y. Šabb. 2:6, 5b, Tanhuma Buber Genesis, p. 28, Leviticus, p. 53. Cf. Anthony Saldarini, The Fathers According to Rabbi Nathan (Avot de Rabbi Nathan Version B) (Leiden: Brill, 1975), 83 n. 10. 
the last three decades to reappropriate, through redefinition and reinterpretation, areas of observance once reserved for women. Such efforts seek as much to link the experiences of contemporary women with that of our foremothers as to create a meaningful framework within which to celebrate the uniqueness of being a female member of the Covenant as women enter the mainstream of Jewish observance long barred to them. Some women have turned to the celebration of menses and immersion in the mikveh as a Jewish Our Bodies Ourselves, an affirmation of the wholeness of our bodies, created in God's image and functioning according to God's will, with the generative potential that enables us to be partners with God in creating life. ${ }^{8}$

Some Jewish women have also embraced mikveh, which traditionally served as a powerful symbol of transformation, ${ }^{9}$ as a symbol of healing and renewal. Women visit the mikveh to mark the renewed hope for pregnancy upon completing the first menstruation following a miscarriage. Some immerse to strengthen prayers for the ability to carry life in cases of infertility. Others seek holiness following rape or wholeness following a hysterectomy or a mastectomy. While all these situations are covered by the gomel prayer, recited upon recovering from illness, some women find that the public setting of the gomel prayer, recited following an aliyah to the Torah during services and in front of the congregation, seems too public for such a private grief. Instead, countless women have found profound comfort in immersing in the primordial waters of the mikveh, whose source comes directly from heaven.

There is another aspect of these laws that relate not only to the woman, but to a woman within the context of a loving and committed relationship. For millennia, the laws of niddah were seen as contributing to the stability and sanctity of a marriage. On one hand, a period of monthly abstinence transformed the marital relationship from one solely focused on sexual satisfaction to one

8 Grossman, "Feminism, Midrash, and Mikveh," 13 n. 2.

9 The use of the mikveh to symbolize transition and change of status is as ancient as its use to purify (a change of status from impurity to purity), e.g. m. Miqw. 8:1 ff., and for conversion (a change of status from non-Jewish to Jewish), e.g., b. Yev. 47a. For an interesting discussion of the significance of mikveh in conversion, cf. Michael Chernick, "Mikveh: A Medium for Change of Status," Journal of Reform Judaism 35 (Spring 1988): 61-64. As for the existence and use of the mikveh in antiquity, cf. Encyclopedia Judaica 11:1541-1544, s.v. "Mikveh." For an example of first-century mikvaot, cf. Yigael Yadin, Masada: Herod's Fortress and the Zealots' Last Stand (New York: Random House, 1966), 164-167. For more scholarly discussions, see Ronny Reich, "Archaeological Evidence of the Jewish Population at Hasmonean Gezer," Israel Exploration Journal 31, nos. 1-2 (1981): 48-52; his "The Hot Bath-house Baleum, the Miqweh and the Jewish Community in the Second Temple Period," Journal of Jewish Studies 39 (Spring 1988): 102-107; and Bryant Wood, "To Dip or Sprinkle:The Qumran Cisterns in Perspective," American Schools of Oriental Research Bulletin 256 (Fall 1984): 45-6o. 
founded upon intellectual and interpersonal companionship and compatibility. On the other, a period of monthly abstinence served to regularly rekindle the physical desire between a man and a woman that might otherwise become stale over the years. Sometimes it is what we cannot have that we most desire. Enforced separation and the concomitant setting aside of time for the resumption of sexual intimacy each month, something that may otherwise be ignored in modern times due to our busy lifestyles, ideally can help support the long term health of a marriage.

It is true that we are obligated to observe regardless of our ability to find compelling significance and meaning (taamei mitzvoth). This is why, for some women, it is enough to observe the niddah laws simply because they are commanded to do so; hilkhot niddah are mitzvot, part of the received tradition of how we live as Jews in service to God.

In light of all of the above, and for all those seeking to make sense of how we relate to the Torah and its commandments, the Levitical laws relating to menstruation can offer a deep, meaningful and beautiful opportunity to sanctify our intimate relationships and express our profound appreciation for having been created in God's image.

\section{Biblical and Talmudic Evolution}

Let us begin our discussion with Leviticus 15. For the sake of brevity, I will cite only those verses dealing with the woman in a ritual state of impurity, though the chapter contains parallel verses for a man.

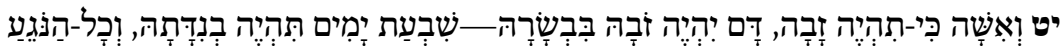

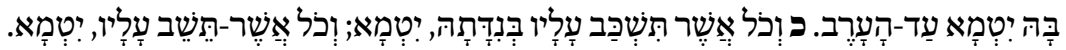

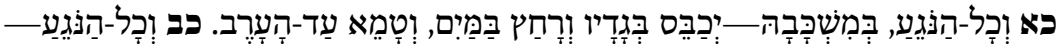

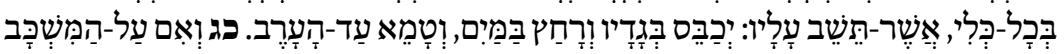

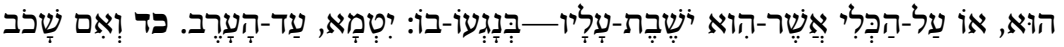

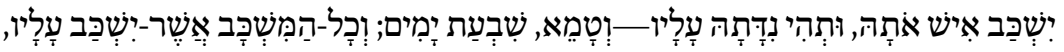
יִטְמָא.

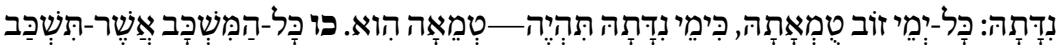

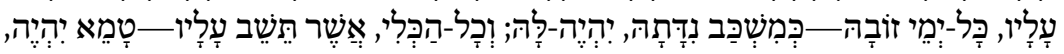

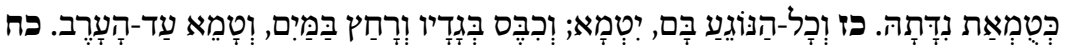

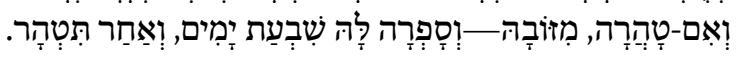

19 When a woman has a discharge, her discharge being blood from her body, seven days will she be in her infirmity and all who touch her will be impure until evening. 20 And anything she lies on during her infirmity will be impure and anything she sits on will be impure. 21 And anyone who 
touches her bedding shall launder his clothing and wash in water and be impure until evening. 22 And anyone who touches any object on which she sat, shall launder his clothing and wash in water and be impure until evening. 23 And whether it was bedding or an object on which she sat, on touching it, he shall be impure until evening. 24 And if a man surely lies with her, her infirmity is communicated to him, and he shall be impure seven days and any bedding that he lies on will be impure. 25 And if a woman have an issue of her blood many days not in the time of her impurity, or if she have an issue beyond the time of her impurity; all the days of the issue of her uncleanness she shall be as in the days of her impurity: she is unclean. 26 Every bed whereon she lieth all the days of her issue shall be unto her as the bed of her impurity; and every thing whereon she sitteth shall be unclean, as the uncleanness of her impurity. 27 And whosoever toucheth those things shall be unclean, and shall wash his clothes, and bathe himself in water, and be unclean until the even. 28 But if she be cleansed of her issue, then she shall number to herself seven days, and after that she shall be clean.

Leviticus 15 deals with four types of individuals, grouped in two categories, who contract ritual impurity through a genital discharge: The zav and zavah, a man or woman who suffer an irregular genital discharge, on one hand, and the ejaculant and menstruant, the man and woman with normal genital flows, from semen and from menstruation, respectively, on the other.

The $z a v$ and $z a v a h$ are required to wait seven days after the discharge ceases, immerse in mayim hayim (literally living water, such as a spring or river, now understood to be a mikveh, or ritual pool) and bring a sacrifice before being fit to reenter the sancta (the Tabernacle and later the Temple) as part of the

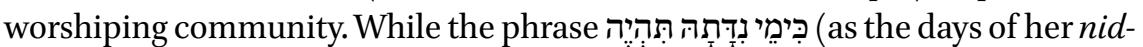
$d a h)$ in verse 25 above could be read to imply that all the restrictions relating to the niddah should be applied to the zavah, including that of prohibiting sexual relations, the Torah does not specifically prohibit having sexual relations with a zavah, even though it specifically repeats all the other rules regarding contact with items that would have come in contact with the woman's blood flow, already delineated regarding the menstruant. Similarly, though the Torah in Leviticus specifies the severe punishment of $k a r e t^{10}$ for a man who lies with a menstruant, ${ }^{11}$ it does not do so for a man who lies with a zavah.

\footnotetext{
10 Karet, literally being cut off, is understood to mean being excommunicated from the community or having one's life cut short prematurely by God.

11 Lev 18:19, 29.
} 
The ejaculant (the man experiencing a seminal emission, referred to in later rabbinic literature as a baal keri) is required to wait one full day and then wash (but not specifically in mayim hayim) before reentering the sacred precincts of the Tabernacle. If he has relations with a woman, she similarly takes on his ritual impurity and is required, like him, to wait until evening and bathe. ${ }^{12}$

The menstruant waits seven full days (presumably to allow for the conclusion of the menstrual flow). While the text does not specify that she must wash at the end of seven days, most commentators assume she is so required. This is consistent with the fact that, as with the other categories, the text requires someone who merely touches her linens, etc., to wash. However, immersion is not required by the peshat (the literal meaning) of the text. Physical contact with anyone experiencing a genital discharge is not otherwise restricted, except for touching anything in direct contact with their genital discharge (e.g., bedding, a saddle, clothes or through intimate relations). Such contact spreads the contagion of ritual purity which is to be subsequently purified as specified in the chapter depending on the category of ritual impurity.

The categories of the zav and zavah on one hand and the menstruant and ejaculant on the other represent only a few of the myriad of categories of impurity within the ritual purity system operative from the time of the Tabernacle until the destruction of the Second Jerusalem Temple in 70 CE by the Romans.

Much has been written about the purity and impurity system in the Torah and its significance. ${ }^{13}$ Some scholars have focused on the role of the purity system in social control, e.g. the control of sexuality. ${ }^{14}$ Others have suggested the mythic symbolism that the central sanctuary served as locus of activity for the perfect human being, who does not experience death. In such a construct, anyone who has a life leak, understood as anyone with a bodily discharge, would be barred from the sacrificial rites. ${ }^{15}$ (This is perhaps why a dead body is the most serious and powerful form of ritual impurity and the ritual for its purification the most complex. ${ }^{16}$ Judaism as a religion that sanctifies life, makes a distinction

12 Lev 15:16-18.

13 E.g., Tikva Frymer-Kensky, "Pollution, Purification and Purgation in Biblical Israel," The Word of the Lord Shall Go Forth: Essays in Honor of David Noel Freedman, ed. Carol Meyers (Winona Lake, In: Eisenbrauns, 1983), 399-414; Jacob Neusner, The Idea of Purity in Ancient Judaism (Leiden: Brill, 1973); Milgrom, Leviticus 1-16.

14 E.g., Douglas, Purity and Danger, 114-158, cf. 41-57; Janice Delany et. al., The Curse: A Cultural History of Menstruation (New York: Dutton, 1976); Penelope Shuttle, The Wise Wound: Eve's Curse and Everywoman (New York: Marek, 1978).

15 E.g.: Rachel Adler, "Tumah and Taharah-Mikveh."

16 Num 19. 
between life and death in removing death from its ritual center and ritual officiants. Even today, a priest, a kohen, is prohibited from participating in a funeral or entering a cemetery except for immediate family.)

Most, though not all, of the laws of ritual impurity fell into disuse with the destruction of the Temple by the Romans in $70 \mathrm{CE}$.

With the destruction of the Temple in $70 \mathrm{CE}$, sacrifices could no longer be brought. It was therefore no longer possible to prepare the ashes of the red heifer for the purification ceremony necessary to cleanse one from contact with the dead. A supply of ashes from the last red heifer, sacrificed before the destruction of the Temple, seems to have been available through part of the rabbinic period, since the cultic laws of ritual purity regarding sanctified food items remained in effect for a period of time after the Temple's destruction. ${ }^{17}$ Since then, no purification from contact with the dead has been available and therefore all Jews, from that time on, can be considered to fall within the category of tumat met, impurity from contact with the dead, which is a highly contagious form of impurity. ${ }^{18}$ Immersion not being a sufficient purification for tumat met, anyone who immersed, even in a mikveh, remained as impure, tameh, after immersion as before immersion. ${ }^{19}$

For all intents and purposes, therefore, the ritual purity system had been flattened so that all Jews were, and are, in the same state of ritual impurity regardless of any individual's physiological condition.

While the Mishnah still retains the laws referring to the ritual purity system, for example in Seder Tohoroth, the Talmud contains a gemorah on very few of them. ${ }^{20}$ The abandonment of these categories of ritual impurity made sense

17 See for example, b. Nid. 6b. Cf. Mishneh Torah, Hilkhot Tumat Okhlim (The Laws of Impure Foods) 16:8-11. Joseph L. Blau suggests that, while some ashes of the Red Heifer (necessary for purification after contact with a corpse) remained available for a limited time following the destruction of the Temple, the many post first century rabbinic references to the ashes of the red heifer may reflect eschatological references to the restoration of the Temple. Joseph L. Blau, "The Red Heifer: A Biblical Purification Rite in Rabbinic Literature," Numen 14, no. 1 (1967), esp. 72-73.

18 The Beta-Israel community in Ethiopia retained the biblical purity laws, including that of the red heifer. See Emanuela Trevisan Semi, "The Beta Israel (Falashas): From Purity to Impurity," Journal of Jewish Sociology 27 (1985): 103-114. A note of appreciation to Shaye Cohen for pointing out this and several other sources cited in this teshuvah.

19 Similarly, the sacrifice to complete the period of zavah could also not be brought.

20 The notable exception in Seder Tohorot is Tractate Niddah. Other tractates may have been compiled for the Palestinian Talmud but are no longer extant. The Babylonian Talmud contains nine of the 11 tractates in Kodashim, none of which are extant in the Palestinian Talmud. Hermann L. Strack, Introduction to the Talmud and Midrash (New York: Atheneum, 1972), 66-67, 358. The only reference to Mishnah Zavim in the Talmud 
within the context of the collapse of the purity system for want of a functioning sacred center in the Temple. In addition, the sacrifices necessary for the purification rituals of a number of impurity categories (such as for the $z a v$ and zavah) could no longer be brought.

Even so, vestiges of the purity system remained actively part of Jewish life for several centuries, though no longer centered around the Temple. ${ }^{21}$ The category of $z a v$, for men who had a non-seminal genital emission, became operationally non-functional by the second century, as evidenced by the fact that Mishnah Zavim does not have a gemorah. (See also below for a discussion about how Rabbi Akiva effectively eliminated the application of the category). ${ }^{22}$ However, the rules for the ejaculant remained in effect longer, as men who had experienced a seminal emission were prohibited from engaging in words of Torah or reciting benedictions. ${ }^{23}$ The Talmud offers a reason: so that the Sages would not behave like roosters, always seeking relations with their wives. ${ }^{24}$ In this way the sexual purity laws served to provide religio-social control over the male sex drive.

As such, the rabbinic tradition regarding ejaculants became stricter than that required by the Torah. Such strictures are attributed to a takanah (an ordinance) by Ezra:

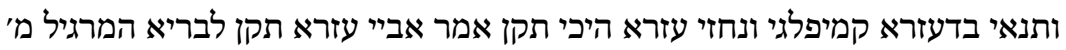

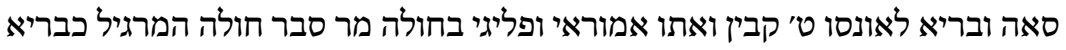

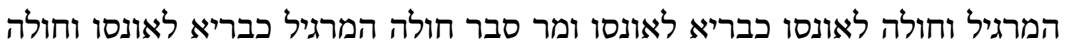

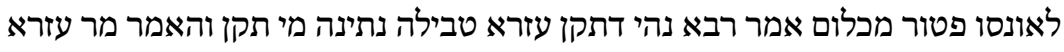

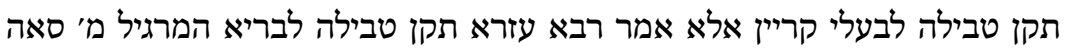

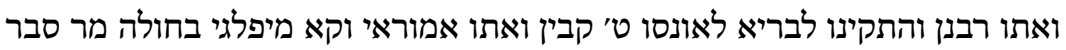

(b. B. Meș. 105b, citing m. Zabim 3:1) does not refer to a zav at all. Rambam does include the zav in his comprehensive Mishneh Torah, Hilkhot Metamei Mishkav v'Moshav (The Laws of Impurity Imparted By Those who Lie and Sit), see especially 5:Iff, although Karo, discussing mitzvot still operative, does not include a section on zavim in his Shulhan Arukh, Yoreh Deah.

21 I will focus only upon the purity aspects relating to bodily emissions, rather than other expressions of the purity system, such as those relating to food and vessels.

22 m. Zabim 2:2. Cf. this discussion in Judith Hauptman, Rereading the Rabbis (Boulder, co: Westview Press, 1998), 154-156.

23 Attributed to a takanah promulgated by Ezra, b. B. Qam. 82a-b.

24 b. Ber. 2ob-22b; m. Ber. 3:4-6; t. Ber. 2:13, ed. Zuckermandel; y. Ber. 3:4, 6c. See Shaye Cohen, "Purity and Piety: The Separation of Menstruants From the Sancta," in Daughters of the King: Women and the Synagogue, ed. Susan Grossman and Rivka Haut (Philadelphia: Jewish Publication Society, 1992), 107 and 114 n. 8. Note that women, whether as zavot or menstruants, are not included in these restrictions and so would be permitted to engage in prayer and the study of the Torah and laws. 


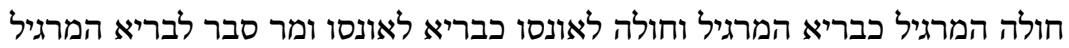

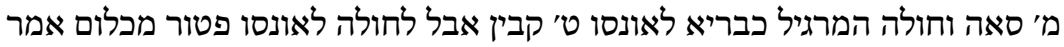

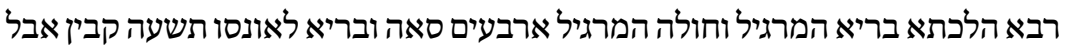
לחולה לאונסו פטור מכלום.

The dispute between all these Tannaim and Amoraim is as to the ordinance of Ezra. Let us see then what Ezra did ordain! Abaye said: Ezra ordained that a healthy man whose emission is voluntary must immerse in forty se'ahs, and a healthy man whose emission is involuntary must use nine kabs, and the Amoraim came and differed over the sick person. One held that a sick person whose emission is voluntary is on the same footing as a healthy person whose emission is voluntary, and a sick person whose emission is involuntary as a healthy person whose emission is involuntary; while the other held that a sick person whose emission is voluntary is on the same footing as a healthy person whose emission is involuntary and a sick person whose emission is involuntary requires nothing at all. Raba said: Granted that Ezra ordained immersion, did he ordain throwing? Has not a master said: Ezra ordained immersion for persons who have had a seminal emission? Rather, said Raba, Ezra ordained for a healthy person whose emission is voluntary forty se'ahs, and the Rabbis [after Ezra] came and ordained for a healthy person whose emission is involuntary nine kabs and the [Tannaim and] Amoraim came and differed with regard to a sick person, one holding that a sick person whose emission is voluntary is on the same footing as a healthy person whose emission is voluntary and a sick person whose emission is involuntary as a healthy person whose emission is involuntary, while the other held that a healthy person whose emission is voluntary requires forty se'ahs and a sick person whose emission is voluntary is on the same footing as a healthy person whose emission is involuntary and requires nine $k a b s$, while a sick person whose emission is involuntary requires nothing at all. Raba said: The law is that a healthy person whose emission is voluntary and a sick person whose emission is voluntary require forty se'ahs, a healthy person whose emission is involuntary requires nine $k a b s$, and a sick person whose emission is involuntary requires nothing at all. ${ }^{25}$

Even though the restrictions on the ejaculant were derived from a takanah, these restrictions were already falling into disuse even among segments of the 
rabbinic class in some Jewish communities during the Talmudic period. ${ }^{26}$ By the time of Maimonides in the eleventh century, restrictions on the ejaculant had been generally abandoned..$^{27}$ Maimonides writes:

\section{ועזרא ובית דינו תיקנו שלא יקרא בעל קרי לבדו משאר הטמאין, עד שיטבול; ולא

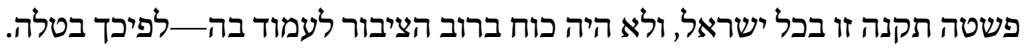

And Ezra and his Court ordained (tikkenu) that an ejaculant, in particular among those who are [categorized] as impure, not read [the Shema] until he immerses. But this ordinance (takanah) did not spread among Israel and the congregation [of Israel] did not have the strength to uphold it, therefore [the ordinance] was annulled. ${ }^{28}$

Maimonides explains that the takanah was annulled for two reasons: because it did not become widespread among the people of Israel and because the majority of the tzibbur (the community of the observant) did not have the strength to maintain it.

The application of the commandments of Leviticus 15 regarding women, however, not only remained in force but were expanded over the centuries to broaden the social restrictions under which the menstruant, and by extension all women, functioned within Jewish society. (See the discussion below.)

One reasonable explanation for why Leviticus 15 remained in force for women at all is because it was linked to Leviticus 18:19, prohibiting sexual relations with a niddah.

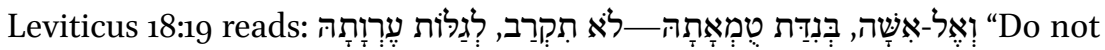
come near a woman in her period of impurity to uncover her nakedness."

So, for example, the mid-second century sage Rabbi Meir teaches:

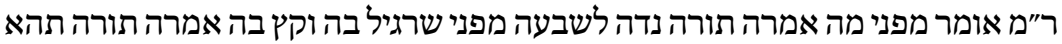 טמאה שבעה ימים כדי שתהא חביבה על בעלה כשעת כניסתה לחופה.}

26 y. Ber. 3:4, 6c records that Hanina (first generation Amorah) ridicules the sages of Israel as "morning bathers." b. Ber. 22a records a tradition in the name of R. Zeira (third generation Amorah) that those in Israel had abolished immersion as a requirement for the baal keri.

27 Except for those who preferred to be mahmir (strict with themselves) and thus retain such strictures, as explained, for example, in Taz on ợ 88.

28 Mishneh Torah, Hilkhot Kriat Shema 4:8, Hilkhot Tefillah 4:4-6, Shulhan Arukh, ợ 88, cf. Magen Avraham, on оң 88, s.v. veahar kach bitlu, and Tur, oł 88 Cf. Cohen, "Purity and Piety," 103-115. Note also that immersion was not unanimously required. See R. Elliot Dorff in his Rabbinic Letter on Intimate Relations for the Rabbinical Assembly, p. 43, n.32. 
Rabbi Meir used to say: Why did the Torah say (that the status of) niddah (lasts) seven days? Because (if) he (the husband) would become accustom to her (his wife), he would loathe her, (therefore) the Torah made her impure for seven days so that she would be as beloved to her husband as at the moment she entered the huppah. ${ }^{29}$

Rabbi Meir, clearly speaking to other men from the male perspective, argues that "absence makes the heart grow fonder," suggesting that the Torah ordained a seven day period of abstention from relations with the menstruant because, if men could have their wives whenever they wanted them, they would develop a loathing for them.

While Rabbi Meir's explanation is homiletic in nature, that the Torah ordained seven days of abstinence to enamor a woman to her husband, there is more than a homiletic message here (though see below for a discussion on the contemporary significance of supporting marital sanctity): relying upon the concepts that ulfi darcheinu lamadnu (and according to our practice it is deduced) ${ }^{30}$ and afilu sihat hulin shel talmidei hachamim tsericha limud (even the casual conversation of Torah scholars demands study),, ${ }^{31}$ we can safely posit that this teaching reflects Rabbi Meir's position on the proper observance of the laws relating to the menstruant, namely that abstinence was required for seven days and seven days only.

It is important to note the halakhic implications of Rabbi Meir's teaching here. Rabbi Meir assumes that the total time of separation between the husband and the wife is seven days (not 12 or 14). This means that he interprets the law as requiring abstinence for the seven days of the woman's menstrual flow. He does not require any additional white days, clearly following the peshat of the Biblical verses of Leviticus cited above. ${ }^{32}$ In other words, the tannaitic practice was clearly that menstruants observed sexual abstinence only for the seven days, counted from the beginning of their menses. ${ }^{33}$ This is supported by the fact that Rabbi later stringency assumes this earlier tannaitic practice.

29 b. Nid. 31 .

$30 \quad$ m. Sukkah 2:1.

31 b. Sukkah 21 .

$3^{2}$ b. Nid. 31b, cf. Rashi, ad. loc. Rabbi Meir seems to be assuming that women are only observing seven days of separation from the onset of their menstruation. The suggestion that he would assume abstinence during menstruation was a given by his male listeners and therefore only had to explain the extra seven days, seems less compelling. See Milgrom, "Comments," 935. On Rabbi Meir speaking from the man's point of view (i.e. the man's interest in his wife), cf. Adler, "In Your Blood, Live," 38-41.

33 Citing b. Nid. 69a., Hauptman, Rereading the Rabbis, 156, goes farther, arguing that all rab- 
By the end of the second century, we see a different observance pattern possibly developing:

\title{
אמר רב יוסף אמר רב יהודה אמר רב התקין רבי בשדות ראתה יום אחד תשב ששה

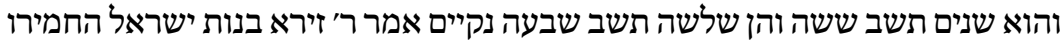 על עצמן שאפילו רואות טפת דם כחרדל יושבות עליה שבעה נשת שישרים
}

\begin{abstract}
R. Joseph, citing Rab Judah who had it from Rab, stated: Rabbi ordained at Sadoth: if a woman observed a discharge on one day she must wait six days in addition to it. If she observed discharges on two days she must wait six days in addition to these. If she observed a discharge on three days she must wait seven white days. R. Zeira stated: The daughters of Israel have imposed upon themselves the restriction that even if they observe a drop of blood of the size of a mustard seed they wait on account of it seven white days. ${ }^{34}$
\end{abstract}

This ruling of Rabbi (Rabbi Judah Ha-Nasi, the editor of the Mishnah) is traditionally understood as conflating the restrictions on the menstruant with those of the zavah, so that a menstruant remained impure for seven additional days after the end of her bleeding just like a zavah. ${ }^{35}$ Rashi, picking up on the mention of Sadoth, explains that it was because Sadoth was a community where the women were unable to distinguish between their niddah and zavah days. ${ }^{36}$

By the fourth century, the Palestinian sage R. Zeira reports that Banot Yisrael, the daughters of Israel, took upon themselves the stricter category of zavah and

binic practice (not just tannaitic) was to require only seven days total for the menstruant.

34 b. Nid. 66a. As Rabbi Judy Hauptman notes, Rabbi's words are cryptic According to Rashi (s.v. shishah v'hu; shana'im) Rabbi treats the blood of the first and second days as menstrual blood and only with the third day treats her as a zavah (Hauptman, Rereading the Rabbis, 157 ff.).

35 Hauptman, Rereading the Rabbis, 158, understands it differently: that Rabbi, and by extension Rabbi Zeira, are speaking only about zavot, not menstruants. Therefore, women took on the extra stringency not for their periods but only in case of intercycle staining.

36 Rashi, b. Nid. 66a, s.v. sadoth. Cf. Mishneh Torah, Hilkhot Issurei Biah 11:3, Magid Mishneh, ad loc. On the problems with the rabbinic efforts to establish a process for determining the days of niddah and zavah by counting cycles of 7 and 11 days, and the confusion such a system engendered since it is inconsistent with biological reality, see m. Nid. 4:4,7 and Meiri on b. Ber. 31a. The Shulhan Arukh is silent on the 7/11 counting system and instead relies on the fact that most women have a standard period (veset) by which they can distinguish between menstrual and zavah blood (Yoreh Deah, 183, 184). 
extended it to whenever they saw a stain as small as that of a mustard seed. ${ }^{37}$ In other words, the takkanah Rabbi promulgated for the conditions relevant for Sadoth remained in force because Banot Yisrael continued to observe it as their minhag (custom). ${ }^{38}$ (See below for the halakhic implications of this for today.)

\section{Women and the Ritual Purity System}

While the restrictions on the menstruant may have remained in force largely because of their association with the prohibition of sexual relations with a menstruant, as delineated in Leviticus 18:19, the language and psychology of ritual purity and impurity that shaped these laws were carried over from their

\section{7 b. Nid. 66a.}

38 According to Rabbi Roth, in a private interview. In addition to whatever difficulty they may have had in distinguishing between different types of blood, these women may have had other reasons as well for supporting Rabbi's takkanah. The Biblical archaeologist and scholar Carol Meyers suggests that these women sought to free themselves from being dependent upon the male rabbis for an interpretation of a woman's monthly cycle. Carol Meyers, Discovering Eve: Ancient Israelite Women in Context (New York: Oxford University Press, 1988), 36-37. Their decision to extend the days of sexual abstention may also have been an effort to affect a form of birth control. Ancient medical knowledge assumed a woman was most fecund immediately after menstruation. Cf., 2 Sam 11:2-5 (in which Batsheva conceives with David shortly after washing, which the text explains as mitkadeshet mitumatah, sanctifying herself from her impurity). According to the historian Keith Hopkins, this knowledge was widely known and used as a form of birth control (as an ancient rhythm method) by women of many social stations in the Roman world. Cf. Keith Hopkins, "Contraception in the Roman Empire," Comparative Studies in Society and History 8 (1965-1966): 124-151, esp. 140 and n. 47. (My appreciation to Seth Schwartz for familiarizing me with this source and to David Kraemer for suggesting this subject.) Cf. Mishneh Torah, Hilkhot Issurei Biah 11:15, in which Rambam applies the harsh term apikorsot (apostates) to parturients who refuse to have relations with their husbands for the entire biblically proscribed purification period (probably to allow themselves to heal). Other scholars, most notably Saul Lieberman in such works as Greek in Jewish Palestine: Studies in the Life and Manners of Jewish Palestine in the II-IV Centuries C.E. (New York: Jewish Theological Seminary, 1942), have demonstrated the level of familiarity and integration of Roman knowledge and culture in the Palestinian Jewish community of which these women would have been part. It is perhaps not unreasonable to suggest that the daughters of Israel sought to reduce their chances of becoming pregnant by extending the time for which they would not engage in sexual relations and thereby missing what they thought to be their most fertile time of month. It is important to remember that, until modern times, many women died in child birth. (Of course, for many women today, ovulation occurs right at the end of the extra seven "white" day period of abstention. Nevertheless, the concern for infertility has generated much discussion on how to help women whose ovulation occurs during the seven white days. See full discussion on infertility below.) Either way, one could posit the desire by Banot Yisrael to exert control over their own bodies even in a man's world. 
cultic setting in Leviticus 15. This may have been part of a larger trend reflecting the rabbis growing concern with ritual purity in the home, in general, as expressed through washing of the hands before eating and other observances. ${ }^{39}$ We also begin to see restrictions on the menstruant carried over to sacred ritual. This is not surprising since the identification of a niddah, menstruant, as one defiled and a source of defilement, is an ancient one. Although not present in Leviticus as a negative value, the term niddah already appears as a negative symbolic motif as early as the work of the sixth-century B.C.E. prophet Ezekiel. ${ }^{40}$ By the end of the Rabbinic period, a text called Baraita de Niddah, which scholars posit comes from sixth or seventh century Palestine, seeks to revive the purity and impurity system by extending it to all areas of religious life in the home and synagogue. The text places restrictions on ejaculants and prohibits menstruants from preparing food for their families as well as from reciting prayers, touching a prayer book or Torah Scroll, or entering a synagogue. ${ }^{41}$

While restrictions regarding ejaculants do not become widespread, the restrictions regarding menstruants spread throughout the women's communities of Europe, often feeding superstition. So, for example, no less eminent a scholar than Nahmanides, commenting on Genesis 31:35 (where Rachel explains she cannot rise because the way of women is upon her), writes:

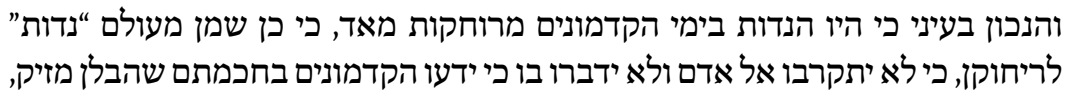

39 t. Šabb. 1:14 seems to indicate that the rabbinic class prohibited eating with a menstruant to maintain the cultic purity of the table, cf. Saul Lieberman, Tosefta Kepeshuta Shabbat. 12-13, lines 33,34 (Jerusalem: Jewish Theological Seminary, 1992) and Avot de Rabbi Natan A ch. 2, Schechter, pp. 8-9, in which the menstruant is not permitted to eat with her husband. There is some discussion about whether women lived separately during their menses, cf. m. Nid. 7:4, on a house of isolation and Rashi, b. Nid. 56b, s.v. Beit Tuma'ot; Roš Haš 26a, in which R. Akiva reports that in the Roman area of Gaul they call the niddah a galmuda, segregated, Cf. AdRNB ch. 42 Schechter p. 117, saying that the menstruant is driven from her home (grushah mbeitah). Cf. Milgrom, "Comments," 949; and Susan Grossman and Rivka Haut, "From Persia to New York: An Interview with Three Generations of Iranian Women," in Grossman and Haut, Daughters of the King, 220. Archaeologist Avraham Faust suggests, based on excavations of a Biblical period Israelite four room house, that menstruants were separated for purity reasons within the home during the Iron Age. See his article, "Purity and Impurity in the Iron Age," BAR 45, no. 2 (March/April 2019): $36-43,60,62$.

$40 \quad$ Ezek 36:17, 25 .

41 Yedidyah Dinari, "The Violation of the Sacred by the Niddah and the Enactment of Ezra" [in Hebrew], Teuda 3 (1983): 17-37; and "The Customs of the Impurity of the Niddah" [in Hebrew], Tarbiz 49 (1979-1980): 302-324; Cohen, "Purity and Piety." 
גם מבטן מוליד גנאי ועושה רושם רע כאשר בארו הפילוסופים, עוד אני עתיד להזכיר

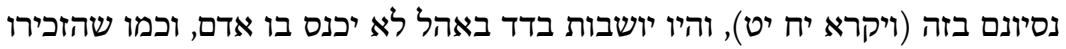

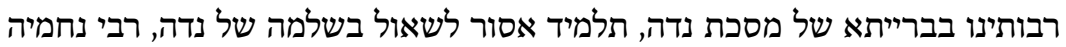

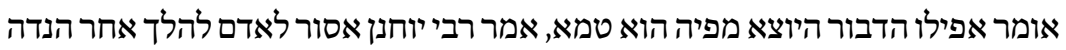

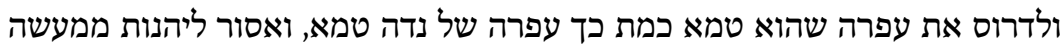

The correct interpretation appears to me to be that in ancient days, menstruants kept very isolated, for they were ever referred to as niddot on account of their isolation since they did not approach people and did not speak with them. For the ancients in their wisdom knew that their breath is harmful, their gaze is detrimental and makes a bad impression, as the philosophers have explained. I will yet mention their experiences in this matter. And the menstruants dwelled isolated in tents where no one entered, just as our Rabbis mentioned in the Beraitha of the Tractate Niddah: "A learned man is forbidden to greet a menstruant." Rabbi Nechemyah says, "Even the utterance of her mouth is unclean." Said Rabbi Yochanan: "One is forbidden to walk after a menstruant and tread in her footsteps, which are as unclean as a corpse; so is the dust upon which the menstruant stepped unclean, and it is forbidden to derive any benefit from her work."42

Ramban, Commentary on the Torah: Genesis, trans. Charles B. Chavel (New York: Shilo, 1971), 387-388. Milgrom, "Comments," 936-937, notes that this isolation was in contradistinction to the tendency of the Torah to minimize the impurity of the menstruant, limiting such impurity to the items that may have been touched by her menstrual flow, i.e. those things she sat upon, as opposed to her touch or her breath, as held in other Ancient Near Eastern cultures.

Little is known about Beraitha de Niddah (ed. Chaim M. Horowitz, Tosefta Atiqata, 1889). Scholars generally agree to its Palestinian origin around the geonic period (c. 1000 C.E.). Milgrom, "Comments," 948, notes that restrictions on the involvement of the menstruant in household chores contradicts вт Ket. 61a. Nevertheless, ethnographic studies indicate that in Persia, Jewish women refrained from touching family food or dishes during their menses; see Susan Grossman and Rivka Haut, "From Persia to New York: An Interview with Three Generations of Iranian Women," trans. Parvin Khoubian, in Grossman and Haut, Daughters of the King, 219-220. The eldest informant spoke about being treated as "a dead mouse," isolated in the corner of her house during her menses.

There are some indications that women were isolated during their menses even before and during the rabbinic period:Josephus writes that menstruants were secluded until the seventh day. Josephus seems to equate these days with the days of isolation observed by the leper and the one having contact with a corpse, which might imply the same seven days following cessation of contact with the impurity (Ant. 3.11.3; Loeb, 261). t. Šabb. 1:14 seems to indicate that the rabbinic class prohibited eating with a menstruant to maintain the cultic purity of the table, cf. Saul Lieberman, Tosefta Kpeshuta (Jerusalem: Jewish 
By the sixteenth century, the major Ashkenazic authority, the Rema, Rabbi Moses Isserles, while acknowledging that such traditions have no basis in Jewish law, encourages women to refrain from touching a Torah scroll, entering a synagogue, touching a prayer book, or reciting prayers. ${ }^{43}$ Traditional communities of Iranian women, for example, also observed the severe restrictions of the Baraita de Niddah until their Westernization through modern urbanization and immigration. ${ }^{44}$

Interestingly, all the classical commentators and codifiers who mention these traditions note that such observances are not grounded in Jewish law but are "women's traditions." 45

Regardless of the reason, the extension of the original Toraitic exclusion of menstruants from the sancta (of Tabernacle and then Temple) effectively excluded women from public synagogue life. Despite a fine article by the Orthodox Rabbi Avi Weiss explaining why women cannot defile a Torah, ${ }^{46}$ many Orthodox synagogues today still refuse to allow women to touch the Torah scroll.

Vestiges of this tradition can even be found today in the folk piety of women in Conservative congregations who still refuse to touch a Torah scroll either

Theological Seminary, 1992), 12, lines 33-34; and Avot de Rabbi Natan A ch. 2, Schechter, pp. 8-9, in which the menstruant is not permitted to eat with husband; m. Nid. 7:4, on a house of isolation, cf. Rashi, b. Nid. 56b, s.v. Beit Tuma'ot, b. Roš Haš. 26a, in which R. Akiva reports that in the Roman area of Gaul they call the niddah a galmuda, segregated, Cf. AdRNB ch. 42 Schechter p. 117 , saying that the menstruant is driven from her home (grushah mbeitah). Cf. Milgrom, "Comments," 949.

In Ethiopia, Jewish menstruants and parturients were also segregated in a menstrual hut, during which time all their household duties are taken care of by other women in their family. Ethiopian immigrants to Israel complain of how difficult it is, for example, to have a new child on one's own and not have the community support to allow the mother to rest and recover during her period of isolation. Cf. Emanuela Trevisan Semi, "The Beta Israel (Falashas): From Purity to Impurity," Journal of Jewish Sociology 27 (1985): 103-114.

43 Rema to Shulhan Arukh, о̣̣ 88. For a complete discussion, see Shaye Cohen, "Purity and Piety," 103-115.

44 Grossman and Haut, "From Persia to New York," 219-220.

45 The historian Shaye Cohen has posited that women initiated and spread these traditions as a way to express their piety. Excluded from meaningful involvement in synagogue services or communal leadership, women grasped those aspects of observance within their power: protecting or defiling the sanctity of the synagogue and its most sacred object, the Torah. See Cohen, "Purity and Piety."

46 Avraham Weiss, "Women and Sifrei Torah," Tradition 20, no. 2 (Summer, 1982), 106-118. His defense is based upon the idea that a Torah cannot contract ritual impurity. He still assumes that menstruants are ritually impure. 
all the time or during their periods. Over the last few decades, several questions have been directed to the Committee on Jewish Law and Standards asking whether menstruants can lead prayer services or read from the Torah Scroll. The response has been, and should continue to be, that there is no basis in halakhah, Jewish law, for restricting a menstruant's involvement in the synagogue or any religious role or function.

As we have seen, there is no halakhic basis for restricting a menstruant from public or private prayer, from serving as shlihat tzibor (prayer leader) or as baalat korei (Torah reader), from access to the synagogue, or from touching a Sefer Torah or other scrolls or holy books. ${ }^{47}$ Conservative congregations would be wise to ignore such customs restricting menstruants because they were never based on halakhah and certainly do not reflect contemporary sensitivities among observant Conservative Jews nor general society, which no longer considers a menstruant a potentially dangerous force or contaminant.

\section{Implications for Contemporary Practice and Halakhic Application}

Jewish observance seems to have gone far a field from Leviticus' original, almost egalitarian formulation that the anthropologist Mary Douglas points out is so "meticulously balanced between the sexes." ${ }^{48}$ As others have pointed out, the Torah establishes a clear parallel between men and women in this parsha, grouping them into two categories: people with irregular genital discharges and people with regular (healthy) genital discharges. ${ }^{49}$ Male and female are treated

47 See, Cohen, "Purity and Piety"; and on touching a sefer Torah, Weiss, "Women and Sifrei Torah."

48 In Reading Leviticus: A Conversation with Mary Douglas, ed. John F.A. Sawyer (Sheffield: Sheffield Academic Press, 1996), 139. Similarly, the Biblical scholar Jacob Milgrom points out that the Torah includes no prohibition barring the menstruant from touching anyone, which signifies that her hands do not transmit contagion. See his commentary, Leviticus $1-16,936$.

49 Kraemer, "A Developmental Perspective," 33; and Mary Douglas, in Reading Leviticus, 139. The seven days ascribed to the impurity of the woman's niddah (meaning literally flow) in Lev 15:19 are understood by David Kraemer and others to be counted beginning with the first day of the woman's menses and constituting the full number of days of the woman's impurity. He argues that limiting to seven days the total number of days a menstruant refrained from sexual activity would more accurately reflect the original intent of the text here (“A Developmental Perspective," 27). Cf. Lev 12:2 ff., regarding the parturient. It is important to note, however, that whenever the Torah mentions seven days in relation to a category of impurity, such a time period refers to the period of purification following cessation of the condition which caused the impurity, for example, following contact with a corpse (Num 19:11), purification of an individual suffering from tzara'at, a scaly afflic- 
alike in all aspects of these laws, except for the seven days allotted to the menstruant, though not to the ejaculant, necessary to distinguish between a normal and irregular discharge. (Parturients are dealt with in Lev 12.)

As we saw above, in the tannaitic period, Rabbi Meir held that only a total of seven days sexual abstinence is required for a menstruant, i.e., for Rabbi Meir, no extra seven white days were required. ${ }^{50}$ Rabbi's takanah also assumes such a tannaitic practice.

This same practice has been the recommended practice (halakhah l'maaseh) for several generations of rabbinical students, and upon ordination, their congregants, as guided by the instruction of Rabbi Joel Roth, a teacher of great piety and one of the preeminent halakhicists of our Movement.

Rabbi Roth comes to his decision based upon the following application of rabbinic law: ${ }^{51}$ It is clear that the two categories of niddah and zavah are distinguishable according to the Torah. While the classical position of Jewish tradition has ignored the distinction in practice, particularly regarding counting an additional seven white days following menstruation, the majority of the Rishonim (excluding Maimonides) do recognize that the distinctions between niddah and zavah are not so complex as to be undeterminable. The fact that Rabbi decreed the takanah at Sadoth presents the takanah as conditional upon the situation at Sadoth, which Rashi understands as the incapability of the women there to distinguish between their menstrual and zivah blood. According to Rabbi Roth, the reference to the town of Sadoth in this baraita, comes to teach us that Rabbi made his decision particularly for the conditions that were operative for the women of the community of Sadoth at that time, specifically that they could not distinguish between their menstrual days and their days of zivah, and not for all women for all time. (This is supported by Rashi, as cited

tion of the skin erroneously identified in the New Jewish Publication Society translation as leprosy (Lev 14:8), and ending the period of impurity for a zav and a zavah (Lev 15:13, 25-30). On the translation of tzara'at as leprosy, see Milgrom, Leviticus 1-16, esp. 823-824. The man who has had relations with a menstruant takes on her impurity and remains unclean for seven days following contact with her (Lev 15:24). Ethiopian Jewish practice, which was unaware of rabbinic tradition, also holds that the seven days of the menstruant in Lev 15:19 are the white days of purification following cessation of the flow. A.Z. Eshkoli, "Halahka and Customs among the Falasha Jews in Light of Rabbinic and Karaite Halakha" [in Hebrew], Tarbiz 7 (1936): 121-125. See the discussion in Milgrom, Leviticus 1-16, 269, 935. However, the concern for the seven white days is eliminated if we are no longer concerned about the ritual purification for which seven white days was required since the destruction of the Temple and the suspension of the sacrificial system.

$5^{\circ} \quad$ b. Nid. 31 b, discussed above.

$5^{1}$ Based upon a private interview with Rabbi Roth and the video lectures he made for the Student Life Office of Jewish Theological Seminary. Any errors are my own. 
above.) In other words, the takkanah was beSadoth, regarding Sadoth, for those women and not our women.

Citing Rabbi Zeira, who credits Banot Yisrael with extending the humra (the stricture) conflating niddah and zavah, Rabbi Roth further argues that the continued conflation of these two categories is a tradition, created by the women, and is not a mandate of law. Precedents exist to stop observing traditions, even strictures however widely observed, which are not grounded in a legal requirement but rather in a mistaken assumption that the custom in question is a legal requirement (rather than a law). ${ }^{52}$ That is the situation here.

Rabbi Roth writes:

This possibility, in turn, raises again the question of the status of customs that are popularly, although mistakenly, thought to be law rather than custom. The Rosh addresses this question too. He writes:

Matters concerning which it is known that they are observed customarily as forbidden because the people wish to be more strict with themselves, you may not declare permitted before them. But if their customary behavior is based upon an error, namely, that they believe that the behavior is actually forbidden when, in fact, it is permitted, you may permit it before them ... Similarly, too, a man whose customary behavior forbids something that is permitted, as a fence or a self-imposed restriction (perishut), no sage ought to declare the act permitted to him. But a sage may permit it to him if he expresses regret (lehattir lahem ha-haratah). [i.e., declares that he regrets having accepted the custom upon himself, and wished to be released from its observance.$^{53}$

By this reasoning, even though Rabbi Zeira knew that the women of his time were in error in choosing to be strict with themselves (i.e. that they were not, in fact, fulfilling an obligation since Rabbi's takanah was only for Sadoth), he would not have declared what they were doing in error because the women themselves were making the decision to be strict with themselves. However, where the observance is in error (that it is custom and not law) and particularly where the individual regrets the custom, the Sage can make permissible what had otherwise been forbidden.

$5^{2}$ This material is available on a tape that Rabbi Roth created for the students of Jewish Theological Seminary. Rabbi Roth concedes that most later poskim would assume the requirement for seven clean or white days as mandate of law, though it is not. 
According to Rabbi Roth, this is the situation in which we find ourselves today: the continued conflation of niddah and zavah was in error (in that it is custom and not law) and the majority of observant Conservative women of our time regret the custom of conflating niddah and zavah (in requiring seven white days for both) and wish to be released from the strictures of its observance. According to the Rosh, they can be so released and what was prohibited (in error) can now be permitted.

We always must be wary of seeking the lowest common denominator of observance and thereby doing damage to the integrity of Jewish tradition and our covenantal responsibilities. That is not the case here. It is true that the majority of observant in our communities found the additional restrictions of Rabbi's takanah so onerous that observance of the niddah laws, even the biblical or tannaitic prohibition of relations for the seven days of menses followed by immersion, was largely ignored by them for decades. However, largely as a result of Rabbi Roth's ruling that makes theses laws sustainable in our community, observance of the niddah laws has grown exponentially among the observant of our Movement. Rabbi Roth's ruling does so not by annulling the law but by re-establishing its precedence over minhag.

My own random sampling of colleagues and observant Conservative women has shown that the majority of observant Conservative women who take seriously the sense of being obligated to Torah and mitzvot, observe mikveh today without the seven extra white days and would object to having to keep an additional seven white days.

Contemporary Conservative women prefer keeping this original tannaitic proscription for many diverse reasons. One reason may be the reality of contemporary society that makes it very difficult for couples to spend time together. An unprecedented number of our congregants are on the road each week traveling for work. When added to obligations for night meetings (for work or community service) plus child care and other responsibilities, couples today find it difficult to attend to the intimate aspects of their lives that is such an important part of a healthy marriage. (This may be one factor in the rising number of divorces, though such a discussion is beyond the scope of this paper.) Under such conditions, the difference between keeping seven or 12 (or more) days of abstinence can make the difference between whether the couple can or cannot have relations that month and whether they will even both try to observe these timeless laws of sexual sanctity.

It must be remembered that, unlike women taking on shofar blowing or omer counting, the extension of niddah into a zavah was a minhag and a humra, rather than the embracing of a hiyuv, a religious obligation. We therefore find 
ourselves with a community of women, and the men with whom they are united, among our most observant members, who "regret" having to be obligated to observe the extra restrictions placed upon them by the application of a takanah by Rabbi, which was promulgated not for us, but for a particular community of women. In such a situation, there is ample rabbinic precedent to allow women to return to the original tannaitic practice of observing only seven days of abstinence beginning with the first day of their menses, and no longer requiring the addition of seven white days following the cessation of blood.

Those who would prefer to continue to observe seven white days may certainly do so. However, the majority of contemporary Conservative women will be able to fulfill the commandment of niddah by the requirement of abstinence a total of seven days beginning with the first day of their menses.

Up until this point we have specifically been discussing the rules of damniddah, a woman's menstrual period. What of dam zivah, blood which appears outside a woman's regular period, also referred to as mid-cycle staining?

Traditional observance required that a woman who had seen a stain (zavah ketanah) wait from day to day, to see if she would stain again, in the meantime refraining from sexual relations. If she stained three days in a row, she "officially" became a zavah (zavah gedolah) which required that sexual relations not be resumed until seven white days were observed after staining stopped (determined by bedikah, internal checking for blood in the vaginal cavity) and immersion was performed in the mikveh.

As we have shown above, the categories of zavah and niddah are distinguishable. Doraita, a menstruant and her husband are explicitly prohibited from sexual relations for seven days. This is a commandment independent of the purity system of the Temple and equally obligatory upon the husband and wife today. Zavah is a different situation, however. As discussed above, the Torah does not explicitly prohibit sexual relations with a zavah.

Once we disentangle the laws and observance of niddah from zavah, zavah can be seen on its own terms.

We have seen, above, that the ritual purity concerns regarding men's genital emissions for a $z a v$ became effectively inoperative fairly early, as evidenced by the lack of a gemorah on it. This is not surprising since much of the purity system collapsed with the destruction of the Temple. As with the baal keri, we cannot reconstruct the exact moment that the laws of $z a v$ became effectively inoperative. However, we do have a tannaitic source that indicates one of the ways the category of $z a v$ began to be inoperative: 


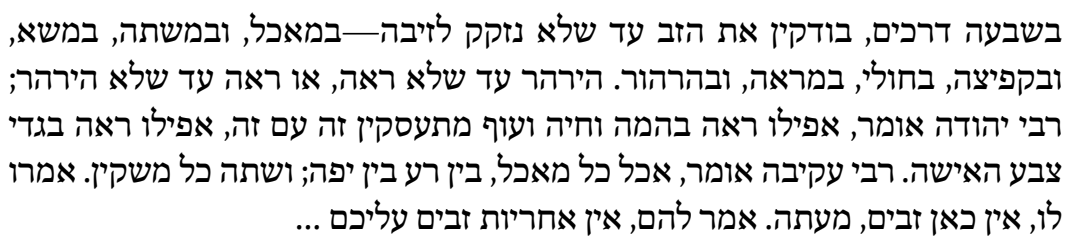

Along seven lines is a $z a v$ examined as long as he had not entered the bounds of zivah: as to his food, drink, what he had borne, whether he had jumped, whether he had been ill, what he had seen, or whether he had impure reflections before he saw or whether he had seen (a woman) prior to his reflections. Rabbi Judah adds: even if he had watched beasts, wild animals or birds having relations with each other, even if he had seen a woman's colored undergarments. R. Akiva says, even if he had eaten any (kind of) food, good or bad, or had drunk any liquid, They said to him, (according to your view) there would henceforth be no zavim in the world. He replied to them: you are not responsible for the existence of zavim ... ${ }^{54}$

The Mishnah challenges Rabbi Akiva on this point, noting that he had effectively made it impossible to consider any man a zav from this point on. $\mathrm{He}$ replies that there is no requirement (any longer) that there be zavim. ${ }^{55}$

For Rabbi Akiva, the essential fact in determining $z a v$ was no longer just the source of the genital emission but also the cause. Thus Rabbi Akiva, while not annulling the law, made it inoperative. Rabbi Akiva defined such a broad variety of sources that would render an emission permissible, that they could essentially be universally applicable, thereby effectively rendering any man suffering a flux fit rather than a $z a v$.

Something similar can be applied to the category of zavah for woman, particularly when there are mitigating circumstances. The most compelling of these mitigating conditions relates to issues of infertility treatment in the Jewish community.

$54 \quad$ m. Zabim 2:2.

55 m. Zabim 2:2; Tiferet Yisrael on m. Zabim 2:2, n. 15. Rambam on m. Zabim 2:2 notes that the halakhah does not follow Rabbi Akiva (or Rabbi Judah) here. However, within a few generations, no one was considered a $z a v$ any longer. It is interesting that Rabbi Akiva held his position, that one does not need zavim, even though he sided with those who sought Jewish independence and presumably the reconstruction of the Temple. 


\section{Infertility and Dam Zivah}

For many reasons outside the scope of this discussion, there is an increased problem of infertility in the Jewish community. More and more couples face great heartbreak in trying to fulfill the mitzvah of peru urvu (be fruitful and multiply) while trying to be observant of Judaism's traditional understanding of the laws surrounding marital sanctity. ${ }^{56}$

Some women struggling with infertility find that they are most fertile during the seven white days following the cessation of their menses, making conception impossible for those following the traditional observance of niddah which requires sexual abstinence during the seven white days. For those, this teshuvah will help by eliminating the need for the white days following regular menstrual flow, allowing sexual relations to resume on the eighth day.

For others, opportunities for conception are restricted by mid-cycle staining.

Orthodox poskim are not unsympathetic to the plight of Jewish infertility. They suggest many ways around considering mid-cycle staining sufficient to require sexual abstinence. ${ }^{57}$

Women are advised to wear colored underwear so the stain is not visible or considered of sufficient color to be considered dam zivah, blood qualifying her as a zavah. Some posekim ignore any stain on a garment, and only count fresh blood, for example on a part of the body. Without commenting on the philosophical implications of such a solution, such a strategy is not efficacious for women who find fresh blood, on their skin, etc. that traditionally would qualify as dam zivah.

Women who experience mid-cycle staining during ovulation can also resort to chemical therapies. However, such medications present possible long-term health dangers to women who sometimes must take these drugs for several years.

Doctors often turn first to clomiphene (also known as Clomid) to treat midcycle staining. This is the same drug used in infertility treatments and is contraindicated where liver disease, ovarian cysts, or a history of ovarian cancer is present. Side effects are generally minor but can include nausea and vomiting along with severe abdominal pain; pelvic pain or bloating; sudden shortness of breath; changes in vision, blurred vision, seeing double, and eye sensitivity to bright light. Clomiphene can also actually reduce mucus, thereby reducing the chances for fertility. A small minority of women may experience more severe

$5^{6}$ See Michael Gold, "Mikveh as a Fertility Problem," in his And Hannah Wept:Infertility, Adoption and the Jewish Couple (Philadelphia: Jewish Publication Society, 1988), 94-100.

57 On counting the seven white days in cases of infertility and other leniencies, see Avrohom Blumenkrantz, Gefen Porioh: The Laws of Niddah (Far Rockaway, NY, 1984), $26 \mathrm{ff}$. 
side effects such as ovarian hyperstimulation which generally disappears without treatment but, without proper monitoring, can become dangerous. Potential complications include kidney problems, liver problems, fluid collection in the lungs and stomach, or twisting of the ovaries.

We are commanded, uvhai bahem ("And you shall live by them", 58 protecting life and health), a mitzvah that overrides all others but three. ${ }^{59}$ Protecting life overrides other mitzvot even in a case of doubt. ${ }^{60}$ As discussed above, when other solutions fail them, observant women who experience staining at ovulation often must resort to chemical treatments that may bring long term complications and health risks. In such a situation, the commandment to protect one's health, uvhai bahem, should take precedence over the restrictions of zavah. Thus, women who have mid-cycle staining no longer need to undergo the pain and, for some, the danger, of manipulating their cycles to merely to avoid mid-cycle spotting.

For other women, the infertility treatments themselves cause staining in a way that would traditionally qualify the woman as a zavah, ironically making conception impossible because intercourse would be prohibited. Such couples are often counseled to utilize artificial insemination, which can be costly financially and emotionally, putting an additional terrible strain on the marriage.

Pru urvu ("Be fruitful and multiply") ${ }^{61}$ is so compelling that, even though women are exempt from this mitzvah, ${ }^{62}$ the Rabbis allowed a husband to be

$58 \quad$ Lev 18:5.

59 Cf. Sanh. 74a (outlining the exceptions for murder, sexual violence, and idolatry).

6o t. Šabb. 15:17 (setting the grundnorm allowing the overriding of other mitzvoth to save a life, even in a case of doubt.) See the discussion in Roth, The Halakhic Process, 183-185. Roth cites the Radbaz who writes: "You asked of me that I inform you regarding one for whom the evaluation was made that (saving his life) required the violation of the Sabbath; yet he does not wish that the Sabbath be desecrated on his account because of piety. Does his wish reflect piety, in which case, it should be honored, or should it not be honored? Response: Indeed, such a one is a foolish Hasid (hasid shoteh) and the Lord will requite his own blood from him for the Torah said, 'And live by them.' Not die by them." (Responsa of Radbaz, pt. 2, no. 1139.)

61 Gen 1:28.

$62 \mathrm{~m}$. Yebam. 6:6. Jewish law traditionally exempts women from the obligation of peru urvu: m. Yebam. 6:6; Shulhan Arukh, Eben Haezer 1; Elliot Dorff, "Artificial Insemination, Egg Donation, and Adoption" (CJLS, 1994), 2-6; David Feldman, Marital Relations, Birth Control, and Abortion in Jewish Law (New York: Schocken, 1978), 46-59. This is because pregnancy endangers her life and one is not obligated to endanger oneself. Such an exemption strengthens the woman's right to protect her health over that of a fetus that endangers her. However, the Talmud recognizes the permissibility to ease halakhic restrictions to enable women to conceive, e.g. b. Yebam. $65 \mathrm{~b}$, in which a woman initiates and is granted a divorce with her ketubah because she wants children and cannot them with her husband. 
forced to divorce his barren wife at her request. ${ }^{63}$ The impact of infertility on the larger Jewish community, let alone the agony experienced by the individuals involved, has always found sympathy within rabbinic jurisprudence. For those women, for whom medical intervention does not effectively stop ovulatory staining, they have no redress: The woman is faced with the terrible dilemma of whether to abandon her commitment to Jewish law and observance to try to conceive even if staining. ${ }^{4}$

There is a larger issue as well. While Jewish fertility is down today for a wide variety of reasons beyond the scope of our discussion, one significant component is the rising infertility crisis among married Jewish women. If ever we, as a Movement, have talked about easing restrictions for reasons of timely need, sh'at hadhak, ${ }^{65}$ the infertility crisis in the Jewish community today should certainly be among the most compelling, particularly where we are not talking about compromising a biblical injunction, but rather permitting the release from a rabbinic stringency.

Rabbi Akiva can provide the precedent to allow us to permit sexual relations when a woman is experiencing mid-cycle staining. How? Rather than determining if someone was a $z a v$ based on the source or nature of a man's genital emission, Rabbi Akiva looked to its cause. He identified causes that were common and therefore could be widely applied so as to effectively include all men, thereby effectively eliminating the instance of zav even though Rabbi Akiva did not eliminate the theoretical category of $z a v$. The same can apply here, particularly since $z a v$ and zavah are analogous biblical and rabbinic categories, which we can see now that zavah has been separated from the separate commandment of niddah. Where the cause of a woman's staining could be the result of diet, medical treatment, physical exertion, or illness, any emission would be considered permissible, and the woman would not become a zavah.

63 Yebam. 65b. For a fuller discussion, see Hauptman, Rereading the Rabbi, 130-146.

64 Rabbi Michael Gold presents a similar dilemma in his book on infertility.

65 See, for example, b. Šabb. 45a (regarding moving the Hanukkah lights); Nid 6a-b, although there is some debate about the efficacy of his ruling in the gemorah, Rabbi Eliezer relies on shat hadakah to rule leniently regarding ritual purity, cf. b. Nid. gb. These two sources also make clear that the restrictions on the menstruant and zavah were firmly rooted within the larger rabbinic approach to the purity rules they imported from the Temple to the homes of the rabbinic class in Palestine concurrent with and following the destruction of the Temple. The farther removed from the Temple, generally fewer were the purity laws observed. 
Effectively, since diet is certainly applicable to all women, therefore, a woman who experiences staining at a time other than her regular period need not refrain from sexual relations (as long as such is medically advisable) or require counting, checking or immersion. While this is particularly helpful to women specifically struggling with infertility, it is not limited to them. ${ }^{66}$

Those who wish to be mahmir (strict with themselves) can do so, refraining from sexual relations when evidence of staining is found, as well as counting seven white days after three or more days of staining followed by immersion. (If ever the Temple were to be rebuilt and the purity system reestablished, the $z a v$ and $z a v a h$ status would be applicable to contact with the Temple and its holy things.)

While one would normally be hesitant to undermine such a long standing tradition, there are mitigating circumstances to do so, and, to paraphrase Rabbi Akiva, we are not obligated to have zavot in the world. ${ }^{67}$ By following the guidelines above, sexual relations in most situations of early ovulation and mid-cycle staining would no longer be precluded. ${ }^{68}$ Thus we would provide real relief for the many observant and religiously dedicated Conservative Jews who struggle to fulfill both the mitzvah of peru urvu (be fruitful and multiply) and the mitz$v a h$ of halakhically appropriate sexual intimacy as well as other women who suffer from medical conditions that cause mid-cycle staining. ${ }^{6}$

\section{The Use of Mikveh}

The Mikveh has been referred to as kissing waters, for it contains fresh water (often rain water) that is specially collected in a way that flows into the mikveh and then "kisses," through a small hole in the wall, water that is more conventionally piped in. ${ }^{70}$ For thousands of years, men and women have found in the warm waters of the Jewish ritual bath, the mikveh, a profound and

66 For example, there are women who have had a hysterectomy, and therefore lack a womb, nevertheless can experience staining as a result of tamoxifen treatments.

67 One could also apply the argument of the Rosh, above, as to the permissibility of permitting a previously observed stricture on the basis that it is merely minhag, even if treated as law, and where, as here, it is regretted. See discussion above, regarding Rabbi.

68 Cf. Gold, "Mikveh as a Fertility Problem," 94-10o.

69 See n. 66 above.

70 A full discussion of the structure and halakhah of the mikveh is beyond the scope of this teshuvah. A naturally occurring body of flowing water (river, lake, ocean) can be used as well (CJLS O2O458B, O71763). Some permit the use of an outdoor pool where no other option is available. See Benjamin Kreitman, Proceedings of the RA, 1969, 219-222. The conversion of a woman who was niddah at the time of her immersion in the mikveh is valid after the fact (CJLS $070678 \mathrm{~B})$. 
transformational experience. Converts were (and continue to be) reborn as Jews through its waters. ${ }^{71}$ Hasidic Masters conversed with God while standing chest deep in its watery shadows. Thousands of generations of women washed away the unrealized potential for life as they began again the miraculous cycle that makes women partners with God in creation.

Mikveh was traditionally observed by Jewish women for three main purposes: Before one's wedding; for pietistic purposes, especially before Yom Kippur and, in some traditions, before Passover; and before resuming sexual activity after a period of abstention (for niddah, zivah, or birth).

It is a tradition for the bride to visit the mikveh the night before her wedding with her closest female relatives and friends. We should revive this tradition of bringing the bride to mikveh. Sephardic communities use this time as the equivalent of a spiritual bridal party, at which close female family members and friends attend the bride as a queen to the mikveh, sing to her while she is immersing in private, and shower her with candies or flower petals as she rejoins them as they sing wedding songs and hold beautiful lit candles. A modern version of this might include going out for coffee (at a kosher restaurant) with one's closest female friends and families after the visit to the mikveh. (See below regarding the role of the groom.)

Prayers are traditionally considered more efficacious when recited in the mikveh, particularly before the third, and last, immersion. This is the source for women taking a moment to add their personal bakashot, personal requests and prayers, to God before their final immersion. This tradition is not restricted to women. Hasidic story collections are full of tales of rebbes who threaten to stand for hours in the mikveh until God reverses the evilness of the decree on someone.

In recent years, the mikveh has also been turned to as a place of healing and recovery after miscarriage, hysterectomy, mastectomy, rape, and therapeutic abortions. $^{72}$

There is ample precedent for these accretions. Regardless of ages and marital status, generations of women have attended mikveh to immerse before Yom Kippur and, according to some traditions, also before Passover. Although not traditionally obligated by Jewish law and tradition (indeed, at one time, not

71 For an interesting discussion of the significance of mikveh in conversion, see Michael Chernick, "Mikveh: A Medium for Change of Status," Journal of Reform Judaism 35 (Spring, 1988): 61-64.

72 See Susan Grossman, "Finding Comfort after a Miscarriage," in Grossman and Haut, Daughters of the King; and Nina Beth Cardin, Tears of Sorrow, Seeds of Hope (Woodstock, vT: Jewish Lights). 
having immersed in a mikveh was considered a sufficient deterrent to premarital relations), such women should not be stigmatized nor made uncomfortable if they would like to utilize the mikveh for such observances. Single women have pointed out that at times they feel the tradition excludes them and punishes them for something over which they have no control. Some single women could use the mikveh as an opportunity to pray that God will send them their beshert, their intended. Others could experience immersion as an opportunity to feel good about themselves within the context of their Judaism.

In a similar vein, post-menopausal woman can also choose to utilize the mikveh, though obviously they would not be required to do so. The question would be, when should post-menopausal women attend mikveh? It seems fitting that in memory of a monthly cycle, a post-menopausal woman could choose to visit the mikveh on Rosh Hodesh (traditionally a woman's holiday) or before Shabbat Mevorchim, the Sabbath on which the New Month is announced which has been adopted as a special Sabbath by most women's davening groups. Alternatively, an individual may choose a special anniversary date, perhaps of getting through an operation or a medical procedure successfully.

Similarly, immersion rituals marking menarche and menopause are appropriate, as are immersion rituals, already mentioned above, for healing following miscarriage, rape, therapeutic abortions, and such surgeries as hysterectomy and mastectomy. (Such immersions would not substitute for the traditional recitation of birkat gomel in the synagogue but would provide support through trying times within the context of one's Judaism that the more impersonal and public recitation of birkat hagomel may make difficult.)

Under this teshuvah, immersion in a mikveh is still required before one's wedding and upon the completion of the seventh day following the beginning of a woman's menstrual flow. (For a fuller discussion of the use of the mikveh, see below.)

A note on men and mikveh is apropos here. Rabbi Joel Roth and others have taught for years that husbands should also go to mikveh before resuming sexual relations with their wives as an expression of the mutuality of their relationship and obligation for the sanctity of their relationship. In addition, similar to the bride attending mikveh before the wedding, a groom could have an equivalent ceremony with his male relatives and friends, a refreshingly spiritual alternative to the bachelor party.

The further development of Conservative mikvaot can make it easier for our congregants to observe any and all of these alternative uses of the mikveh as part of their personal piety and efforts to draw closer to God and their Judaism. 


\section{An Alternative Construction of Significance}

The idea of framing one fourth of a woman's existence within the context of ritual purity continues to drive many women away from embracing the mitzvah not to engage in sexual relations during one's period.

Perhaps a more useful construction for us today regarding women's menstruation would be to turn from the concept of ritual purity and impurity to that of holiness, something to which we all strive and which reflects positive connotations of the highest order.

For all that Rabbi Meir was speaking to men in a way that may sound discordant to our modern sensibilities, there is something to be said for the sweet denial of access to sexual relations to whet the appetite of desire for some people. Perhaps more significantly, particularly in long term marriages and where parents may be running between jobs and childcare, setting aside time at the end of a woman's period to fan the flames of desire is good for marriage. These laws focus attention on the sexual component of the marriage that is often lost as lovers become parents. The obligation to engage in sexual relations upon the completion of the period of abstention (while perhaps logistically challenging in a home hopefully filled with children) helps ensure that attention to each partner's sexual satisfaction remains part of the regular interaction between the partners. (Such conscious attention can also hopefully stimulate more frequent romantic interludes beyond this monthly ritual.) Sexual satisfaction is an element of marital stability. Therefore such observances are good for the longevity of marriage. This is especially important today when marriage itself seems under siege with the rising divorce rate.

A response must be added here to critiques that may acknowledge the benefits of self-restraint and sexual abstinence in a marriage but argue that the couple should be able to choose when to set aside such time and not be restricted to the seven days of a woman's period. To such critiques there are several responses. First, for the faithful, the answer acknowledges that the observance to abstain specifically during the seven days of the woman's menses is the practice received in the Torah, applied by the Rabbis and sanctified by generations of our ancestors. As implied above, changes in such a received tradition, while possible, must be justified by a compelling reason, hopefully such as those made herein.

Second, an answer lies in the nature of communally shared ritual and its power to connect us as a People beyond the boundaries of time or space.

Finally, an answer also lies in the power of a spiritual discipline to raise in the individual a sense of service and purpose beyond one's self. By definition, the rules of that spiritual discipline must come from outside the individual, for 
part of the nature of a spiritual discipline is submitting to an authority higher than oneself. Judaism is not a religion of abstinence. God created us with the natural inclination to enjoy sexuality, as Rabbi Elliot Dorff so eloquently discusses in the Conservative Movements' Rabbinic Letter on Intimate Relations. Just as we control our instinctual drives for food, through kashrut, and for territory and security, through the laws of business ethics, so, too, can we direct our instinctual drive for sex to holy ends through self-control. We can best celebrate the sanctity of a relationship enjoyed with mutual respect, consideration, and self-control through refraining from sexual relations during a regularly set time. As members of a covenantal community we submit to the structure of sexual abstention during a woman's menses for seven days (as defined by the Torah and our Sages, the Tannaim) just as we submit to the laws of kashrut which determines that a cow is kosher and a pig is not.

As valid and important as all these observations are, it would be remiss not to also include the observation by Rachel Adler that such constructions of the laws of menstruation (regarding sexual availability) are troubling when they see women only in relation to men, i.e. as a sexual partner, rather than as primarily in relationship to God as our Creator and Commander. ${ }^{73}$

Under the influence of modern science, we now understand menstruation as a natural process. Freed of superstition, self aware of primal fears, and recognizing women as equal members of our covenantal community, perhaps we can finally transform what had at one time been seen as a stigma into a celebration of the wholeness and sacredness of woman being created by God with the potential to join God as a partner in creating new life.

Judaism believes we are created by God with a system of ducts and tubes that must open and close and expel and leak appropriately for us to exist. ${ }^{74}$ Unlike in Hellenistic thought, which creates a dualism between the purity of the soul and the degradation of the body, Judaism presents the body as being created in God's image and therefore worthy of care and respect ${ }^{75}$ and important to our wholeness in serving God. ${ }^{76}$ This refers to the female body as much as the male body. Women can finally celebrate the wholeness and sacredness of being created by God with the potential to join God as a partner (along with

\footnotetext{
73 Adler, "In Your Blood, Live," 38-41 (rebutting her first article).

74 This is expressed in the Asher yatzar prayer recited daily.

75 Gen 1:27, cf. the story about Hillel, Lev. Rab. 34:3.

76 This is one possible reason for the importance of resurrection as a foundational belief of the Pharisees and Rabbis according to Will Herberg, Judaism and Modern Man (New York: Atheneum, 1983), 229.
} 
their spouses) in creating new life, made possible by the ebb and flow of their monthly menstrual cycles.

Observance of a woman's menstrual period through self-care and reflection, followed by immersion in the warm waters of the mikveh with its blessing, then, can become part of a ritual designed to raise within us a radical sense of appreciation and wonder, like the rituals of reciting the blessings on going to the bathroom, eating, or engaging in a myriad of other normal human functions. Such blessings, expressing appreciation for being created as we are, can be pertinent to all women, whether married or single, sexually active or celibate.

Such a reinterpretation may require a reconfiguration of the language that surrounds the development of these laws in a way that captures this sense of holy awareness. The language of Tohorat HaMishpahah, popularized in the early twentieth century, ${ }^{77}$ carries with it not only the negative connotations of the ritual purity/impurity system, but also the focus on a woman only when she is married, in relationship with a man.

Maimonides writes:

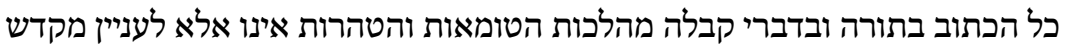

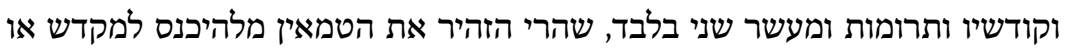
לאכול קודש או תרומה ומעשר בטומאי בלבד.

Whatever is written in the Torah and in traditional teaching about the laws relating to things impure and pure is relevant only to the Temple and its hallowed things and to heave-offering and second tithe, for it warns those impure against entering the Temple or eating anything hallowed, or heave-offering, or tithe in impurity.78

That is true here as well.

I have elsewhere suggested we substitute the traditional usage of Tohorat HaMishpahah (the purity of the family) with the language Kedushat HaMishpahah, the sanctity of the family. ${ }^{79}$ While retaining the focus on the beauty and sanctity of the marriage, which has value in this age of trying to keep families together, such language nevertheless ignores the very real challenge of defining women's experience as women in relation to God rather than just in relation to men.

77 My appreciation to Rabbi Miriam Berkowitz for researching this point.

78 Mishneh Torah, Tumat Okhelim 16:8.

79 Grossman, "Feminism, Midrash, and Mikveh," 14-15. 
Today, I would revise that suggestion with the substitute terminology Kedushat Yetzirah, the Sanctity of Creation, or the sanctity of a created being. This terminology has many significant allusions, i.e., to the female form of created being (ytzir-h), to creation itself (as partners in creation) (ytzirah), to self-control (kibush hayetzer). ${ }^{80}$ Either of these terms (Kedushat Mishpahah or Kedushat Yetzirah) offer an authentic Conservative contribution to the evolution of halakhic ritual language.

The term for a menstruant would be based on the more neutral term for blood, dam, following current Israeli colloquial usage, as in ishah medamemet, instead of the term niddah, which we have seen above has negative connotations of spiritual impurity and sinfulness. ${ }^{81}$ This is also why I do not prefer what others might consider the neutral language of Hilkhot Niddah in referring to these laws.

Using the language of kedushah focuses us on the command to be holy that culminates the list of sexual commandments in Lev. 18, the source for refraining from sexual relations during menses. More importantly, it focuses us on the real reason we do this: to bring holiness into our lives through Jewish observance even in our most personal experiences.

It is important to note that the commandment to mark one's menses (Lev.15) was not given in the Torah to married women, but to all women. While immersion in that ritual context outside of sexual activity is not required (hayav), all women, not just those in a sexual relationship, may have the desire to enjoy the spiritual benefits of monitoring their cycles and immersing in a mikveh.

\section{Summary of Details of Observance}

1. Ritual Purity: Women today know their bodies and can distinguish between dam niddah and dam zavah.

a. In response to a question received by the CJLS whether a menstruant imparts impurity to that which she touches: Today, when the

8o In a previous paper, "Feminism, Midrash, and Mikveh," I had suggested the terminology "Kedushat Mishpahah." However, a growing number of single Jewish women have expressed interest in celebrating the cycle of potential life that God has given them through their periods. In light of the requests of some of these women, and in consideration of the critique of Adler, "In Your Blood, Live," 38-41, who argues against mitzvot directed at women that do not treat the woman as the commanded, I now prefer this broader category that moves beyond the narrow definition of the family to encompass the broader category of God's creation and creative powers.

81 Similarly, the suggestion by Rabbi Miriam Berkowitz to substitute the more normative Hilkhot Niddah, while accurate and preferable to Tohorot HaMishpahah, has the disadvantage of carrying with it the historical negative connotations of impurity. 
Temple no longer stands, the menstruant does not impart impurity to the items she touches or sits upon, to others who touch her, or the things the others have touched, or sat upon. No ritual restrictions are to be placed upon a menstruant. There is no halakhic basis for restricting a menstruant from public or private prayer, from serving as shlihat tzibor, from access to the synagogue, from touching or reading from a Sefer Torah, or other scrolls or holy books, or serving in, or participating in, any other ritual role or function. ${ }^{82}$

2. Seven White Days: The categories of niddah and zavah are distinguishable. The custom to conflate the two, while representative of tradition, is not a binding legal mandate. Therefore, a menstruant need not observe seven white days following the cessation of her menses. She must observe the minimum requirement of seven days of abstinence, the counting for which begins with the first day of her menses, followed by immersion.

a. While seven white days are no longer required before immersion and the subsequent resumption of marital relations, ${ }^{83}$ any women who prefers to follow the tradition of observing the extra seven white days may, of course, do so.

3. Sexual Relations: The menstruant should refrain from sexual relations for seven days beginning with the first day of her flow. She can immerse after the seventh day, or after the cessation of blood flow, if longer than seven days. (See below for more details)

a. Because this is a mitzvah about sexual self control, and because we, as a Movement, have recognized and provided guidelines about sexual relations prior to marriage, ${ }^{84}$ these laws are obligatory upon all sexually active adults, not only when the partners are married.

i. There is a ladder to aspiring to holiness as we walk towards God's holy mountain, to utilize the imagery from our Movement's statement of belief, Emet $v$ Emunah. For some that may mean participating in a loving, committed relationship that hopefully will someday culminate in marriage. Applying these laws to the unmarried does not blur the boundaries between

\footnotetext{
82 See Cohen, "Purity and Piety"; and on touching a sefer Torah, see Weiss, "Women and Sifrei Torah."

83 Rabbi Roth has been counseling rabbinical students for years that they need not count the extra seven days following cessation of the woman's period, but merely wait one day to be sure the period is over.

84 In Rabbi Elliot Dorff's Rabbinic Letter on Sexual Intimacy.
} 
marital relations (which are encouraged) and pre-marital relations (which are discouraged) as much as it hopefully motivates thoughtful and mature discussions and decisions about whether to engage in premarital relations with a significant other.

b. Although a full discussion regarding parturients, particularly the differentiation of periods of abstinence based upon the child's gender, is beyond the scope of this paper, couples should abstain from sexual relations for at least two weeks following birth (or one week after the birth of a boy, in the case of a particular hardship during which both partners desire sexual intimacy). However, couples should not resume relations until the woman feels she is sufficiently healed, physically, to be able to enjoy intimate relations.

4. Determining the Beginning and End of Menses: For our purposes, a menstruant would be defined as one experiencing her menstrual flow. While the normal menstrual flow (a veset, regularly occurring period) has traditionally been understood to be from three to seven days, we can rely on a woman's acumen that she can distinguish for herself when her flow begins and ends, even when her periods are irregular and even when her period runs for more or fewer days than the 3-7 average. In the case of abnormalities, the woman can rely on the expertise of her doctor and can consult her rabbi.

a. We can rely on the woman to notify her partner when sexual relations should be suspended, i.e., when the woman feels the onset of her period is imminent. If a woman gets her period when the couple is in the middle of relations, the couple merely separates. ${ }^{85}$

b. Bedikah, internal inspection, is not necessary before resumption of sexual relations because we assume women know when their periods are completed. A woman who is particularly pious and has had a period of irregular length can choose to inspect herself (bedikah) with a soft cloth or check her tampon ${ }^{86}$ to be extra sure she has completed her period. If a woman is unsure whether she is finished with her menstrual flow, she should wait one day to determine whether

85 See Teshuvot Poskim Uminhagim, R. Meir Bar Barukh M. Rotenberg (Maharam), ed. Yitzhak Zev Kahana, vol. 2 (Jerusalem: Mosad HaRav Kook, 1957), 146, cf. sheilot 9o-103.

86 Although Orthodox halakhah frowns on the use of a tampon because it cannot reach every part that needs to be checked (Gefen Porioh, 29, 219 n. 21), b. Nid. 66a seems to offer a precedent for its use, especially since newer tampons are designed to be soft, absorbent, and expansive. 
her period is over, unless such a wait would endanger the possibility of conception in the case of infertility. (See below.)

c. The woman must wait the requisite seven days from the first day of her period before attending mikveh and resuming relations.

d. In the case of infertility problems, and if there are medical reasons why waiting until the eighth day to resume relations is problematic, the woman should consult with her rabbi to see if there is a way to start her count earlier. For example, in the rare case where a woman ovulates on the seventh day from the beginning of her full flow, if she began staining several days preceding her full flow, and her full flow only lasts five days, it may be possible to count the days of staining that preceded the start of her full flow as the beginning of her actual flow and therefore part of the requisite seven. Then what might appear as the seventh day (if counted from the beginning of a full flow) really is the eighth, ninth or tenth day and is therefore permitted, since the counting could begin from the day she first began staining. This leniency should only be relied upon for special cases of extenuating circumstances regarding infertility.

5. Mid-Cycle Staining: We assume that mid-cycle staining is caused by one of a variety of external reasons (diet, medicine, treatment, physical exertion, illness) which would be permitted and therefore such blood would not be considered dam zivah prohibiting sexual activity.

a. In all cases of infertility, we should be makil (lenient).

b. When ovulation can take place during the period where a woman continues to experience bleeding or staining continuously beyond her seventh day, and when a woman is battling with infertility, even here we can assume this is permissible blood (as above) and therefore mikveh can take place and sexual relations can be resumed. This is important because ovulation for some women occurs immediately following their periods or coincides with staining. In such cases, the mitzvot of pekuach nefesh ${ }^{87}$ (protecting the woman's life from the long term effects of drug therapy) and peru urvu (procreation) take precedence. (For how to determine the end of a woman's menses for women without a compelling need, see above.)

6. Physical contact during the week of abstinence: We live in a society that, while sensitized to sexual harassment and abuse, also treats touch-

87 On pekuah nefesh: e.g., b. Šabb. 151b, Halal alav Shabbat ahat kdae shyshmor Shabbatot harbeh. (One should transgress this one Shabbat in order that one may observe many Shabbatot.) 
ing between sexes very casually. Therefore, even during a period of sexual abstention, types of physical contact which provides support, comfort, and companionability (such as that appropriate between adult siblings) can, and should, continue. A handshake, a hug, holding someone's arm, shoulder or hand (especially in times of illness or stress, such as at a funeral or in the hospital), even a kiss on the cheek or a light kiss on the lips is common between relatives and friends of opposite sexes, with no sexual innuendo. Therefore, some physical contact can continue between partners during the woman's menstruation as long as it is limited to that which is generally accepted in society between siblings. ${ }^{88}$

a. Under these guidelines, partners should not sleep in the same bed unless clothed and should exercise modesty in undressing and dressing in front of each other during this time period. Newlyweds (and especially unmarried sexually active partners) must be particularly careful not to be drawn into physical intimacy which we might colloquially describe as necking or heavy petting.

b. One or both partners might very normally experience this period of sexual abstinence as a time of submerged tensions, of feeling ignored or of experiencing self-doubt. This time of sexual abstinence should be utilized by the couple not to ignore each other, but to heighten their sensitivity to each other, perhaps by putting aside time for extensive and intimate discussions. The couple may choose to utilize this time to study together some of the extensive literature that is available that helps us better understand how intimacy functions in our relationships. The week of sexual abstinence then can serve as an opportunity for doing the serious interpersonal work that helps strengthen the foundation of the marriage, particularly around honest and intimate communication. In this way, the period of sexual abstention becomes a time to reaffirm the nonsexual component, the intellectual and emotional partnership, of the relationship. ${ }^{89}$ Hopefully, such conscious effort during the days of abstinence can infuse the entire relationship, throughout each

88 Whereas, previously it would have been prohibited, even to the extent of not passing anything to each other and not sleeping in the same bed, even when dressed, all in order to provide a fence by which to protect against touching that might lead to conjugal relations. Cf., Num. Rab. 10:8 which prohibits embracing, kissing, conversation, and sleeping together, and discourages the menstruant from beautifying herself. R. Akiva reversed the latter, arguing that a woman should not appear repugnant to her husband, b. Šabb. 64b; cf. Saldarini, $A d R N B, 44-45$, nn. 1-5.

89 My appreciation to R. James Michaels for suggesting this. 
day of the month, with such sanctity that each partner can see the other, in every interaction, as an equal reflection of godliness worthy of deep and abiding respect and concern, as I and Thou, according to Martin Buber's beautiful construction of the ideal possible in relationships.

c. Although a full discussion of the parturient is outside the scope of this paper (particularly regarding the fact that the gender of the child determines the length of sexual abstinence), regarding physical, non-sexual, contact: the partner can be present during birth and should not hesitate to touch the birthing woman to support her during the birthing process and to give comfort and support during the weeks following birth, as outlined above in paragraph 6 .

7. Mikveh: Immersion in the mikveh should take place after the seventh day following the beginning of menses.

a. Immersing while having a flow does not transmit impurity to the mikveh. ${ }^{90}$ Therefore in the case of a woman who is experiencing staining after the seventh day, she may attend mikveh, particularly if she is grappling with infertility and resuming sexual relations after the seventh day will help support the infertility treatments or is on advice she has received from her doctor.

b. Ideally, both members of the couple should try to immerse in the mikveh. ${ }^{91}$ Most mikvaot today have time periods set aside for women and men, to protect modesty.

c. Women can immerse in the mikveh during daylight, b'odyom..$^{92}$ Certainly for reasons of safety, but even for convenience to encourage mikveh use, mikvaot should set aside regular hours for women to attend the mikveh during the day, in which case the woman would immerse on the day following the end of her period.

d. The mikveh should be open to any women who would like to immerse (e.g. singles, brides, women going for healing ceremonies, or just for pietistic reasons not related to their periods or particular health or fertility concerns).

9o The water of a proper mikveh cannot become impure. Responsa Chatam Sofer, Yoreh Deah 213. This implies that for those who permit the use of a swimming pool as a mikveh (see above herein), where there is continued staining, a swimming pool should not be relied upon.

91 Rabbi Joel Roth has been recommending this for years to rabbinical students.

92 Shulhan Arukh, Yoreh Deah 197:4 permits daytime immersions when there is concern for safety. 
e. We in the Conservative Movement should encourage the building of Conservative mikvaot and the use of mikvaot.

f. We should reintroduce the tradition of bringing the bride to the mikveh and develop a parallel ceremony for the groom as a substitute for the bachelor party.

8. Making the time of resumption of relations special: The night following the completion of the woman's menstrual flow can be a special romantic interlude. This is especially important for today's couples who often find themselves so busy with dual careers or, even in one career families where with the daily challenges of raising kids, partners often have little time to themselves to keep the romantic spark alive between them. The night following the completion of the woman's menses and immersion in the mikveh should be set aside whenever possible for the couple to spend together. Parents can arrange for a sitter and go out. (Possibly they can first go to the mikveh and then out to dinner.) This can be a night to set aside for enjoying the special mitzvah of sexual relations within marriage. In long term relationships (marriages of ten years and more), this ensures that a sexual component remains alive as part of the relationship.

a. When ovulation takes place later than the eight day, and where there are infertility concerns, the couple may wait until the day of ovulation to resume sexual relations so as to maximize chances for conception..$^{93}$

9. Choosing to be Mahmir (Stricter): Anyone who prefers to be mahmir, stringent with themselves, may continue to observe seven white days, as long as doing so does not pose a possible danger to the woman's health (for example, by relying on medical intervention that would be necessary only to conform to the mahmir position) for to do so is not piety but prohibited foolishness. ${ }^{94}$

10. Language and Context: The term Tohorat HaMishpahah continues to be loaded not only with negative implications and symbolism but also very real social stigma for women today. That changing language is difficult should not eclipse the significant changes being initiated that would help spread observance and help ameliorate the challenges faced by infertile couples. Therefore, we will just suggest here that, for those who have the interest and the will, that more positive language can be substituted for

93 This follows medical guidelines to maximize the amount of semen that can be available during ovulation.

94 Cf. Responsa of Radbaz, pt. 2, no. 1139. See Roth, 183-185. 
the relatively new term Tohorot HaMishpahah which, we should remember, only became popular in the last century. Kedushat Mishpahah may appeal to some who seek to strengthen the focus on family. Kedushat Yetzirah is a more neutral term that focuses on each woman's direct relationship with, responsibility to, and appreciation of God. In either case, instead of referring to the menstruant as a niddah, which has carried a negative connotation since later Biblical and rabbinic literature, the menstruant can be called by the more neutral term ishah medamemet, which is currently in use in Israel. Similarly, the term Hilkhot Niddah, while preferable to Tohorat HaMishpahah, is not recommended since it continues to be burdened with the negative connotation of niddah. Following a suggestion by Rabbi Miriam Berkowitz, the permissibility of sexual relations can be noted with the simple terminology of mutar (permitted) and asur (prohibited).

\section{Summary}

First it is important to reiterate that even under Jewish law as it currently stands, there are no religious or social restrictions on the role of the menstruant in the synagogue and its rituals. Similarly, under current Jewish law, there is no fear of contracting ritual impurity from contact with a menstruant or with that which the menstruant has sat upon.

When we apply this view consistently to men and women in our communities, we remove the stigma and disadvantages experienced by women by being labeled impure. For centuries now, men have been treated no differently whether or not they are zavim or baalei keri. So too, we can now recognize that women are not to be treated differently for being zavot or nashim medammemot (menstruants). We are all technically in the ritual state of tumat met, impure from contact with the dead. If and when the Temple were to be rebuilt, we could reactivate the detailed observances of these largely inactive categories of ritual purity and impurity.

That said, even with the flattening of the purity system, we are still obligated to self-control in our sexual relations as delineated in Leviticus 18, which proscribes sexual relations when a woman is in her period. The Tannaim held abstinence for only the biblical proscribed seven days. Rebbe conflated the menstruant with the zavah (adding the seven white days of the zavah) at Sadoth. His ruling was for the women there at the time because they did not know how to distinguish between the two types of blood. However Jewish women today can distinguish between the two. Following the Rosh, we can permit that which was previously prohibited where it is based upon minhag (even where it is commonly mistaken for law) and when observance of the stricture is regretted. 
This is the case for the majority of observant women of our Movement, who, unlike their foremothers, regret the obligation of the additional seven white days. Therefore, women need count only seven days from the first day of their period and immerse on the eighth before resuming sexual relations.

We can rely on the earlier rabbinic precedent of Rabbi Akiva to consider the cause, rather than the source, of a genital emission as determinative, and assume that a woman's mid-cycle staining is permissible as the result of diet, medicine, treatment, physical activity, or illness.

This ruling has the immediate advantage of easing the challenges faced by couples who are observant and struggling with infertility therapies, as described above, although it also provides assistance to women encountering mid-cycle staining for other reasons, for example cancer treatment, as well. Therefore, based upon our concern for the commandments of vahai bahem (to protect life and health, even in cases of doubt) and for the emergency concerns of fertility in the Jewish community and for individual couples in their efforts to fulfill the mitzvah of pru urvu (procreation), and since the Torah never explicitly prohibits sexual relations with a zavah, sexual relations are to be permitted during mid-cycle or ovulatory staining, because such staining is considered permissible since it is due to diet, medicine, treatment, physical activity, or illness. When confronted with infertility issues, the local rabbi as morah d'atra should make every effort to be makil.

Finally, in order to support, pedagogically, the embracing of the mitzvah of self control and distinguish it from the negative attributes and disadvantages women have been placed under by the continuing identity of the observance of sexual abstinence during a woman's menstruation with the purity system, it is recommended, though not legislated, that rabbis and teachers begin to utilize a different terminology than has previously been used: substituting for Tohorat HaMishpahah either Kedushat HaMishpahah, the sanctity of the family, or preferably the more neutral term Kedushat Yetzirah, the sanctity of creation, for the entire category of observance, and, in either case, substituting for the word niddah, the more neutral term ishah medammemet, for the menstruant.

\section{Conclusions}

There are no social or religious restrictions on the role of the menstruant in the synagogue and its rituals.

Women should abstain from sexual activity for seven days following the onset of their menses. Sexual relations can resume on the eighth day without recourse to counting seven white days, following tannaic precedent.

Mid-cycle staining does not preclude sexual relations, particularly in the case of infertility, since we assume, based upon tannaitic precedent, that such 
staining is caused by diet, medical treatment, physical exertion or illness. Staining therefore is not to be considered dam zivah that would preclude sexual relations, but rather permitted blood.

It is recommended that the language used to describe this mitzvah reflect concerns for the sanctity of the individual and her family, rather than the negative connotations of the purity system, by relying on such terms as Kedushat HaMishpahah or the more neutral term Kedushat Yetzirah, and referring to the menstruant herself by the current Hebrew term ishah medammemet.

Submitted with Yirat Shamayim by Rabbi Susan Grossman Tishrei, 5767. Revised Lyar 5779 .

\section{Bibliography}

Adler, Rachel. "In Your Blood, Live: Re-Visions of a Theology of Purity." Tikkun 8, no.1 (1993): 38-41.

Adler, Rachel. "Tumah and Taharah-Mikveh." In The First Jewish Catalogue. Philadelphia: Jewish Publication Society, 1973, 167-171. Also published in Jewish Woman: An Anthology. Edited by Liz Koltun, 117-127. Philadelphia: Jewish Publication Society, 1973 .

Blumenkrantz, Avrohom. Gefen Porioh: The Laws of Niddah. Far Rockaway, NY, 1984. Cardin, Nina Beth. Tears of Sorrow, Seeds of Hope. Woodstock, vт: Jewish Lights, 1999.

Chavel, Charles B., trans. Ramban, Commentary on the Torah: Genesis. New York: Shilo, 1971.

Chernick, Michael. "Mikveh: A Medium for Change of Status." Journal of Reform Judaism 35 (Spring 1988): 61-64.

Cohen, Shaye. "Purity and Piety: The Separation of Menstruants from the Sancta." In Daughters of the King: Women and the Synagogue. Edited by Susan Grossman and Rivka Haut, 103-115. Philadelphia: Jewish Publication Society, 1992.

Blau, Jacob L. "The Red Heifer: A Biblical Purification Rite in Rabbinic Literature." Numen 14, no. 1 (1967): 70-78.

Delaney, Janice, Mary Jane Lupton, and Emily Toth. The Curse: A Cultural History of Menstruation. New York: Dutton, 1976.

Dinari, Yedidyah. "The Customs of the Impurity of the Niddah" [in Hebrew]. Tarbiz 49 (1979-1980):302-324.

Dinari, Yedidyah. "The Violation of the Sacred by the Niddah and the Enactment of Ezra" [in Hebrew]. Teuda 3 (1983): 17-37.

Dorff, Elliot. This is My Beloved, This is My Friend:A Rabbinic Letter on Intimate Relations. New York: Rabbinical Assembly, 1996. 
Douglas, Mary. Purity and Danger: An Analysis of Concepts of Pollution and Taboo. London: Routledge and Kegan Paul, 1966; London: Ark Paperbacks, 1984.

Douglas, Mary. Reading Leviticus: A Conversation with Mary Douglas. Edited by John F.A. Sawyer. Sheffield: Sheffield Academic Press, 1996.

Eilberg-Schwartz, Howard, ed. People of the Body: Jews and Judaism from an Embodied Perspective. Albany: SUNY, 1992.

Eshkoli, A.Z. "Halahka and Customs among the Falasha Jews in Light of Rabbinic and Karaite Halakha” [in Hebrew]. Tarbiz 7 (1936): 121-125.

Faust, Avraham. "Purity and Impurity in the Iron Age." BAR 45, no. 2 (March/April 2019): $36-43,60-62$.

Feldman, David. Marital Relations, Birth Control, and Abortion in Jewish Law. New York: Schocken, 1978.

Frazer, James. The Golden Bough. New York: Avenel, 1981.

Frymer-Kensky, Tikva. "Pollution, Purification and Purgation in Biblical Israel." In The Word of the Lord Shall Go Forth: Essays in Honor of David Noel Freedman. Edited by Carol Meyers, 399-414. Winona Lake, In: Eisenbrauns, 1983.

Gold, Michael. And Hannah Wept: Infertility, Adoption and the Jewish Couple. Philadelphia: Jewish Publication Society, 1988.

Greenberg, Blu. On Women and Judaism: A View from Tradition. Philadelphia: Jewish Publication Society, 1981.

Grossman, Susan. "Feminism, Midrash, and Mikveh." Conservative Judaism 44, no. 2 (Winter 1992): 7-17.

Grossman, Susan. "Finding Comfort after a Miscarriage." In Daughters of the King: Women and the Synagogue. Edited by Susan Grossman and Rivka Haut, 284-29o. Philadelphia: Jewish Publication Society, 1992.

Grossman, Susan, and Rivka Haut. "From Persia to New York: An Interview with Three Generations of Iranian Women." In Daughters of the King: Women and the Synagogue. Edited by Susan Grossman and Rivka Haut, 217-225. Philadelphia: Jewish Publication Society, 1992.

Hauptman, Judith. Rereading the Rabbis. Boulder, co: Westview, 1998.

Herberg, Will. Judaism and Modern Man. New York: Atheneum, 1983.

Hopkins, Keith. "Contraception in the Roman Empire." Comparative Studies in Society and History 8 (1965-1966): 124-151.

Kahana, Yitzhak Zev, ed. Teshuvot Poskim Uminhagim, R. Meir Bar Barukh M. Rotenberg (Maharam). Vol. 2. Jerusalem: Mosad HaRav Kook, 1957.

Kaplan, Aryeh. Waters of Eden: An Exploration of the Concept of Mikvah. New York: National Conference of Synagogue Youth, 1976.

Klein, Isaac. A Guide to Jewish Religious Practice. New York: Jewish Theological Seminary, 1979 .

Kraemer, David. "A Developmental Perspective on the Laws of Niddah." Conservative Judaism 38, no. 3 (Spring 1986): 26-33. 
Lamm, Norman. A Hedge of Roses:Jewish Insights into Marriage and Married Life. New York: Feldheim, 1966.

Lieberman, Saul. Greek in Jewish Palestine: Studies in the Life and Manners of Jewish Palestine in the II-IV Centuries C.E. New York: Jewish Theological Seminary, 1942.

Lieberman, Saul. Tosefta Kpeshuta. Jerusalem: Jewish Theological Seminary, 1992.

Meyers, Carol. Discovering Eve: Ancient Israelite Women in Context. New York: Oxford University Press, 1988.

Milgrom, Jacob. Leviticus 1-16. Anchor Bible 3. New York: Doubleday, 1991.

Neusner, Jacob. The Idea of Purity in Ancient Judaism. Leiden: Brill, 1973.

Parker, Robert. Miasma: Pollution and Purification in Early Greek Religion. Oxford: Oxford University Press, 1983.

Reich, Ronny. "Archaeological Evidence of the Jewish Population at Hasmonean Gezer." Israel Exploration Journal 31, nos. 1-2 (1981): 48-52.

Reich, Ronny. "The Hot Bath-house Baleum, the Miqweh and the Jewish Community in the Second Temple Period." Journal of Jewish Studies 39 (Spring 1988): 102-107.

Roth, Joel. The Halakhic Process: A Systematic Analysis. New York: Jewish Theological Seminary, 1986.

Saldarini, Anthony. The Fathers According to Rabbi Nathan (Avot de Rabbi Nathan Version B). Leiden: Brill, 1975 .

Shuttle, Penelope. The Wise Wound:Eve's Curse and Everywoman. New York: Marek, 1978. Strack, Hermann L. Introduction to the Talmud and Midrash. New York: Atheneum, 1972. Trevisan Semi, Emanuela. “The Beta Israel (Falashas): From Purity to Impurity.” Journal of Jewish Sociology 27 (1985): 103-114.

Weiss, Avraham. "Women and Sifrei Torah." Tradition 20, no. 2 (Summer, 1982): 106-118.

Wood, Bryant. "To Dip or Sprinkle: The Qumran Cisterns in Perspective." American Schools of Oriental Research Bulletin $25^{6}$ (Fall 1984): 45-6o.

Yadin, Yigael. Masada: Herod's Fortress and the Zealots' Last Stand. New York: Random House, 1966. 